\title{
From Adversity to Relationality: A Buddhist- Oriented Relational View of Integrative Negotiation and Mediation
}

\author{
RAN KUTTNER*
}

"Flowers don't blossom in the spring; the blossoming of flowers is the spring."

$(\text { Dogen })^{1}$

\section{INTRODUCTION: CURRENT TENDENCIES IN WESTERN THOUGHT AND MEDIATION LITERATURE}

In their book The Promise of Mediation, Robert A. Baruch Bush and Joseph P. Folger claim that in order for mediation to fulfill its promise-that is, its potential to fundamentally transform common adversarial patterns-a different understanding of foundational philosophical questions like "what does it mean to be a human being?" is needed. ${ }^{2}$ The authors claim transformation is needed from an individualistic view of the self, which is rooted in a vision of the individual as a separate being, autonomous and unconnected, to a relational view of the self, where: "Individuals are seen as both separate and connected, both individuated and similar. They are viewed

* B.A., M.A., Tel-Aviv University, Israel; Ph.D., Bar-Ilan University, Israel. Assistant Professor at the Werner Institute for Negotiation and Dispute Resolution, Creighton University, School of Law. Visiting Scholar, Program on Negotiation at Harvard Law School 2005-2008 This article is an adaptation of a chapter from a Ph.D. dissertation Ran Kuttner, Presence of Dialogue in Mediation (2008) (unpublished Ph.D. dissertation, Bar-Ilan University, Program on Conflict Management and Negotiation) (on file with author).

${ }^{1}$ As found in JACOB RAZ, ZEN BUDDHISM: PHILOSOPHY AND ESTHETICS 97 (2007) (Ran Kuttner, trans.).

2 Robert A. Baruch Bush \& Joseph P. Folger, The Promise of Mediation: RESPONDING TO CONFLICT THROUGH EMPOWERMENT AND RECOGNITION, Ch. 4 (1994). In this article I relate to the first edition of the book, as the ideas brought here resemble the themes presented in the second edition, ROBERT A. BARUCH BUSH \& JOSEPH P. FOLGER, The Promise Of Mediation: The Transformative Approach to Conflict (2nd ed. 2004). For differences between the two editions, see Ran Kuttner, Striving to Fulfill the Promise: The Purple House Conversation and the Practice of Transformative Mediation, 22 NEGOT. J. 331 (2006). 
as being to some degree autonomous, self-aware, and self-interested but also to some degree connected, sensitive, and responsive to others." 3

The narrative approach to mediation, as presented by John Winslade and Gerald D. Monk in their book Narrative Mediation, offers a framework that also critically re-examines the common modern Western concept of the "self." Winslade and Monk, following postmodern philosophy, criticize the idea of the "self" as possessing a separate, permanent inner core, emphasizing that a shift is required from the parties' firm, fixed, and wellconstructed view to a realization of their "selves" as being relationally coconstructed. ${ }^{4}$ This paper will follow the claims of both Bush and Folger, and Winslade and Monk that the manner in which the self is perceived by the mediator has a major effect on her mediation approach. As Winslade and Monk assert:

How mediators understand the nature of the self has a bearing on how they manage a dispute between parties. ... problem-solving and interestbased approaches emphasize the individual as an independent, stable, unitary, self-motivating, and self-regulating identity.... Through the postmodern lens, a problem is seen not as a personal deficit of the person but as constructed within a pattern of relationships... From this perspective, identity is not fixed, nor is it carried around by the individual largely unchanged from one context to another. ${ }^{5}$

The questioning of the self as a separate, independent, and fixed entity is one tendency in current Alternative Dispute Resolution (ADR) literature, upon which the transformative and narrative frameworks elaborate. This tendency is also found in twentieth-century thought at large, which involves ontological questioning of Aristotelian metaphysics and Cartesian philosophy regarding the human agent, the subject, or the self. ${ }^{6}$

This tendency also involves a call for more focus on relational emphases, which in late-twentieth century thought became more central in various

3 BUSH \& FOLGER, supra note 2, at 242.

4 John Winslade \& Gerald Monk, Narrative Mediation: A New Approach to CONFLiCt RESOLUTION, Ch. 2 (2000).

${ }^{5}$ Id. at $44-45$.

${ }^{6}$ Nietzsche, Heidegger, Wittgenstein, Foucault, and Deride are prominent thinkers who suggested criticism on common understandings of the self. Phenomenology, Hermeneutics, and Post-Structuralism are central schools in the creation of the intellectual shift, each of them with its unique criticism of the governing western underpinnings and common concept of "self." 


\section{A BUDDHIST-ORIENTED VIEW OF NEGOTIATION AND MEDIATION}

disciplines. $^{7}$ Although integrative negotiation and mediation contain tendencies towards a relational aspect, ${ }^{8}$ unlike the literature of other disciplines, ADR literature still lacks an overarching analysis that would situate these tendencies in a larger picture that takes into account the zeitgeist and tendencies in current thought. Negotiation and conflict literature lacks a thorough investigation of the underpinnings of the relational dimension. ${ }^{9}$ As Tricia Jones writes:

A review of theoretical approaches to conflict and, more specifically, to mediation reveals that relational context has received little attention.... Although mediation theories may include reference to or discussion of relational context, they rarely highlight its potential for

${ }^{7}$ For example, for developments in feminist theory, see CAROL GILLIGAN, IN A DIFFERENT VOICE: PSYCHOLOGICAL THEORY AND WOMEN'S DEVELOPMENT (1982); Linda C. McClain, "Atomistic Man" Revisited: Liberalism, Connection, and Feminist Jurisprudence, 65 S. CAL. L. REV. 1171 (1992). For developments in psychotherapy in the last few decades, as framed under the "Relational Psychotherapy" stream, see RELATIONAL PSychoanalysis: THE EMERGENCE OF A TRADITION (Stephen Mitchell \& Lewis Aron eds., 1999). For relational social constructivist philosophy, see SHEILA MCNAMEE ET AL., RELATIONAL RESPONSIBILITY: RESOURCES FOR SUSTAINABLE DiALOGUE (Sheila McNamee \& Kenneth J. Gergen eds., 1999). For relational frameworks in political science, as will be presented later in this paper, see Daniel Bowling \& David Hoffman, Bringing Peace into the Room: The Personal Qualities of the Mediator and Their Impact on the Mediation, in BRINGING PEACE INTO THE ROOM: HOW THE PERSONAL Qualities OF THE MEdiator IMPACT THE PROCESS OF CONFLICT RESOLUTION 13 (Daniel Bowling \& David A. Hoffman eds., 2003) (describing manners in which new, relational conceptions of the "self" effect various disciplines, and also suggest relevance to the mediation room).

${ }^{8}$ BUSH \& FOLGER, supra note 2; Sara Cobb, Creating Sacred Space: Toward a Second-Generation Dispute Resolution Practice, 28 FORDHAM URBAN LAW J. 4, 1017 (2001); Lois Gold, Mediation and the Culture of Healing, Pp. 183-214 in BRINGING. PEACE INTO THE RoOM: How the PERSONAL Qualities OF THE MEdiator IMPACT THE Process of Conflict Resolution 183 (Daniel Bowling \& David A. Hoffman eds., 2003).

9 Jonathan G. SHAIlor, Empowerment IN Dispute MEdiation: A CRITICAL ANALYSIS OF COMMUNICATION (1994); Leonard Greenhalgh \& Roy J. Lewicki, New Directions in Teaching Negotiations: From Walton and McKersie to the New Millennium, in NEGOTIATIONS AND CHANGE: FROM THE WORKPLACE TO SOCIETY (Thomas A. Kochan \& David B. Lipsky eds., 2003). Tricia S. Jones, A Dialectical Reframing of the Mediation Process, in NEW DIRECTIONS IN MEDIATION: COMMUNICATION RESEARCH AND PERSPECTIVES (Joseph P. Folger \& Tricia S. Jones eds., 1994); 
influence. And, to date, they have failed to seriously unpack how that influence may be exerted.$^{10}$

Her statement, although written in 1994 , is still relevant in 2009 , and the challenge of shifting from the governing discourse, in which "[d]isputants are constructed as expressive and utilitarian individuals," 11 is yet to be met. Greenhalgh and Lewicki stress that even when negotiation manuals claim to adopt relational emphases, the teaching of negotiation is "a convenient simplification, because considering 'the party' as a single generic actor allow[s] scholars to apply all of their individualistically oriented theory to the intra-group, inter-group, intra-organizational, and international levels."12

Another tendency which is identifiable in current ADR literature is a shift towards emphasizing the importance of clarifying the philosophical underpinnings of the mediation approach one holds. Bush and Folger present a four layer structural analysis of mediation models, proposing that each model has a philosophical basis as the foundational layer from which the other layers emerge:

Figure 1

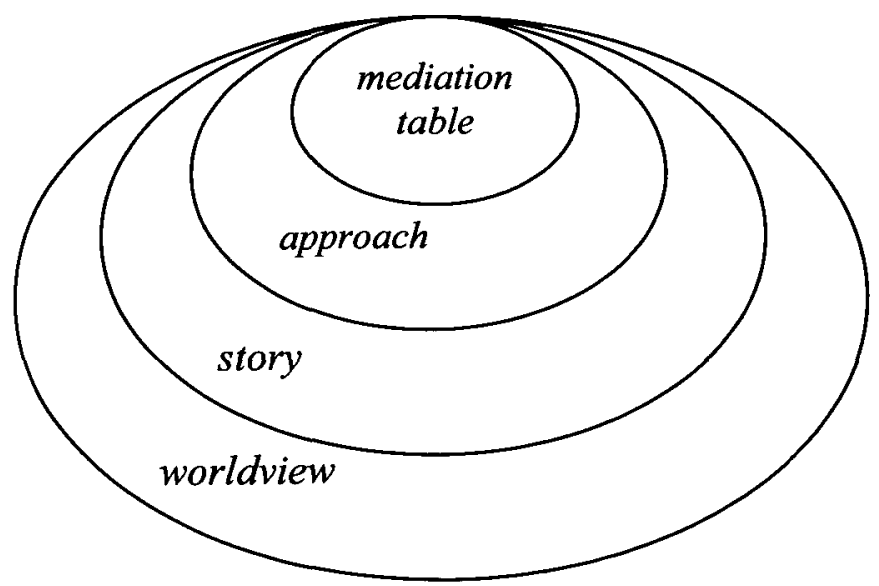

The fourth, innermost layer of the model includes the mediator's observable actions in practice (such as: her opening statement; her way of conducting the process; what she decides to reframe or lack thereof; and the

10 See Jones, supra note 9, at 26, 30.

11 SHAILOR, supra note 9, at 28.

12 Greenhalgh \& Lewicki, supra note 9, at 20, 28. 
way she chooses to intervene). These process choices derive from the third layer: her approach to mediation-her particular understanding of how she should act as a mediator and the set of skills she should use. This general approach, in turn, emerges from the second layer: the story she tells-her understanding of what mediation is and what, respectively, is the role of the mediator. Finally, the mediator's story emerges from the first, most foundational layer: the mediator's philosophical worldview. This philosophical worldview includes her basic view of philosophical areas of inquiry, such as the meaning of being human, our connection to our surroundings, and the nature of human freedom. Bush and Folger claim that a clarification of the foundational outer two layers of the model is essential to allow the mediator to make informed choices ingrained in a "big picture" understanding of the mediation process, and an in-depth orientation to it. Winslade and Monk go even further, claiming that the "narrative" approach to mediation is built more on entering into a philosophical position or mindset than on learning particular techniques: "Those who grasp the philosophical position will relatively easily and quickly master the practices ... [while] [t] ]hose who undertake narrative mediation through a simplistic practical orientation often flounder after a short time and fail to embody the spirit of the approach."13

According to Winslade and Monk, understanding the philosophical foundations and the spirit of Narrative Mediation is not only essential to its skillful practice, but the main mastery needed. Mediation teacher and author Kenneth Cloke highlights the link between the philosophical underpinnings and the practice. He writes:

[T] he roles we play in mediation are largely defined by our own attitudes, expectations, and styles. These roles, in turn, depend on a set of assumptions about human nature, the nature of conflict, and the nature of change that have reverberated throughout Western political and philosophical thought for centuries, resulting in radically different definitions of mediation. ${ }^{14}$

The same argument applies to negotiation and may lay the groundwork for a better understanding of the set of assumptions that complements, if not governs, the roles people play in negotiation. If this is the case, I suggest that it is necessary to clarify the philosophies that underlie the set of beliefs we

\footnotetext{
13 WINSLADE \& MONK, supra note 4 , at 32.

14 Kenneth Cloke, Mediating Dangerously: The Frontiers of Conflict RESOLUTION 9 (2001).
} 
hold, and that govern our practice as mediators and negotiators. The tendencies described above bear an important aspect clarifying the philosophical underpinnings, and showing the manner in which the evolution of mediation and "integrative negotiation" frameworks taking part in a larger transition phase. That understanding may help clarify how mediators can respond to needs people come with which are unique to the times.

A third tendency this paper addresses is the increasing interest in the Buddhist tradition. During recent decades the criticism of the concept of self as separate and permanent has been increasingly reinforced by the growing interest in Eastern traditions at large, and Buddhist philosophy and practices in particular. The premises upon which the Buddhist worldview and method of transformation are based present a significant alternative to Aristotelian metaphysics, which profoundly challenges the work of lawyers and the ADR mediators. As Douglas Codiga writes,

Finally, it must be equally clear that mindfulness meditation offers something more than stress reduction and improved lawyering skills. Interested lawyers must appreciate that mindfulness meditation is a proven method for cultivating deeper insights. ... ${ }^{15}$

ADR scholars ${ }^{16}$ have already begun incorporating Buddhist fundamentals and mindfulness-based practices into the disciplines of Law and Conflict Resolution. ${ }^{17}$ In March of 2002, Harvard Law School held a symposium exploring the subject. It was followed by the Harvard Negotiation Law Review dedicating an Issue to the subject under the title "Mindfulness in Law and ADR." As mentioned, the Program on Negotiation at Harvard Law School held a second symposium on the relations between Buddhist thought and conflict resolution in November 2007, under the title "Buddhism and Dialogue." Author and Professor Michael Wheeler from the Harvard Business School and the Program on Negotiation hosted the symposium. ${ }^{18}$

15 Douglas A. Codiga, Reflections on the Potential Growth of Mindfulness Meditation in the Law, 7 HARV. NEGoT. L. REV. 109, 110 (2002).

${ }^{16}$ Such ADR scholars are Riskin, Peppet, Freshman, Bowling, and Rock, among others.

${ }^{17}$ For more details, see http://www.pon.harvard.edu/events/mindfulness-in-the-lawadr/ (last visited Feb. 22, 2010).

18 For more details see http://www.pon.harvard.edu/events/buddhism-and-dialogueworkshop/ (last visited Feb. 22, 2010). 


\section{A BUDDHIST-ORIENTED VIEW OF NEGOTIATION AND MEDIATION}

However, it is necessary to further elaborate on the philosophical tenets that go hand in hand with the mindfulness-based practice for which most ADR scholars who integrate the Buddhist worldview advocate.

\section{THE RELATIONAL FOUNDATIONS OF THE TRANSFORMATIVE APPROACH}

The aim of the transformative approach is to allow the mediator, and those involved in negotiations or conflict resolution processes, to adopt an alternative mindset. ${ }^{19}$ This claim is not radical in itself; indeed, it is consistent with the message that Roger Fisher and William Ury convey in their path-breaking book Getting to Yes, where they offer a modus operandi of cooperation, and suggest that negotiators can serve their interests and possibly improve their outcomes through a cooperative approach to negotiation. ${ }^{20}$

The preliminary question with which Ury, while formulating a perception of integrative negotiation, opens his book Getting Past No, is how to turn an adversary, a con-frontation, into co-operation. As Ury states in the opening sentences: "This book sprang from a question: How can you turn confrontation into cooperation? How can you transform conflicts to be fought into problems to be solved? ${ }^{21}$

The shift Ury describes, which already exists in Getting to Yes, is from a state of standing in opposition, in front of each other (confrontation), to a state of joined activity, facing the problem together (co-operation). ${ }^{22}$ Unlike the adversarial, confrontational view of negotiation, Ury's view of negotiation suggests a shift from focusing on the "other" as the source of the problem, to focusing on the problem. ${ }^{23}$ It is not the people that are difficult, but the situation. Adopting such a perception may allow the parties to sit at the same side of the table, facing the problem and jointly working on its resolution: "The challenge is to turn a confrontation into an exercise in joint

19 BUSH \& FolgER, supra note 2, at 229-30.

20 Roger Fisher \& William URy, GetTing to Yes: Negotiating AgREement Without Grving IN (Bruce Patton ed., 1981). This message is foundational in other books they write following Getting to Yes.

${ }^{21}$ William Ury, Getting Past No: Negotiating Your Way From CONFRONTATION TO COOPERATION ix (1993).

$22 \mathrm{Id}$. at 5-6 ("Instead of glowering across the table, you sit next to each other facing your common problem. In short, you tum face-to-face confrontation into side-by-side problem-solving.").

${ }^{23} I d$. at 5 . 
problem solving." 24 The aim is that the disputants will shift from holding opposing stances, pushing each other back, and trying to crack the shield of a bounded "other," to sitting side-by-side, as two parties to a conflict, confronting jointly the problem. The shift is from "difficult people" to "a difficult situation." 25 The situation, according to that perception, becomes central for the creation of cooperation.

"Your single greatest opportunity as a negotiator is to change the game," 26 writes Ury. In The Promise of Mediation, Bush and Folger do not suffice with Ury's or Fisher's perspective of "changing the game;" they adopt an alternative worldview, which includes dealing with the philosophical foundations held by negotiators and disputants. In order to truly adopt and incorporate a cooperative mode of behavior as part of one's daily lifestyle, Bush and Folger claim there is a need to "change the game" on a deeper level. ${ }^{27}$ Bush and Folger's broad notion of transformation requires a re-examination of the foundations, an inquiry into the question of human nature: "what does it mean to be a human being? How are we to understand it, understand us?"

Bush and Folger criticize the "individualistic worldview,"28 which they claim is the common worldview of our times. ${ }^{29}$ According to the individualistic worldview, the authors write that human beings view themselves and one another as autonomous entities who, at the peak of their developmental maturity, will achieve the capability to define oneself by himself, separately and distinctively from others, and will define what is

24 This principle already exists and is emphasized in Getting to Yes, being the first principle in Fisher and Ury's method: "Separate the People From the Problem." FISHER \& URY, supra note 20 . The authors open the acknowledgments to their book by stating, "[t]his book began as a question: What is the best way for people to deal with their differences?" Id. at vi; see also WILlIAM URY, THE THIRD SIDE: WhY WE FIGHT AND How WE CAN STOP (2000).

25 "If you want to sit side by side facing the problem, you will need to Step to Their Side." URY, supra note 24, at 12.

26 Id. at 10.

27 BUSH \& FOLGER, supra note 2, at 229.

28 BUSH \& FOLGER, supra note 2 . The following presentation of their analysis does not come to side with the Transformative Approach as presented and advocated for in their book and in succeeding works, but to follow their fundamental analysis of mediation as an alternative in the sense of offering a relationally based practice.

${ }^{29}$ Neal Milner, Mediation and Political Theory: A Critique of Bush and Folger, 21 LAW \& SoC. INQUIRY 737, 747-50 (1996). Milner suggests that Bush and Folger offer a political theory which presents an alternative to the liberal state. 


\section{A BUDDHIST-ORIENTED VIEW OF NEGOTIATION AND MEDIATION}

important for them, based on individual personal preferences and choices. As Bush and Folger say,

what is good and satisfying in life is not objectively definable at all. Rather, it is definable only by each individual for him- or herself. Therefore, attaining the value of satisfaction in general is only possible through attaining the satisfaction of individuals, each of whom defines his or her own good. 30

This is "a view of human nature that emphasizes separateness, autonomy, individuality, and self-interestedness." 31 According to this view, human beings are engaged primarily with themselves and with satisfying their own needs, while others are perceived as instruments in service of reaching that satisfaction. Thus, every human being maintains freedom by self-defining their preferences and needs separately and distinctly from others in an autonomous and independent manner. Furthermore, every human being in a conflict, every party contributing to or taking a side in the conflict is defined separately and distinctly in the broadest sense: whole and free with an independent self-consciousness, possibly influenced by the other, but at its deepest core not affected by the other. The manner by which one is influenced by the other is determined by his personal judgment conducted in a private, autonomous realm, while distancing himself from the other. Selfdetermination, having a solid and distinct self, is the characteristic of human freedom according to the individualistic worldview. ${ }^{32}$ Therefore, one arrives at the negotiation table with the other in order to satisfy and maximize gains and values, defined separately and distinctively.

This worldview, according to Bush and Folger, is common and accepted in modern Western thought, with values deeply rooted in modern Western society. ${ }^{33} \mathrm{~A}$ re-examination of this worldview may suggest an alternative to both these values and the definition of human freedom. ${ }^{34}$

${ }^{30}$ BUSH \& FOLGER, supra note 2, at 235.

${ }^{31} \mathrm{Id}$. at 238.

32 "Indeed, individuality - the capacity of each individual to define and experience the goodness of life in his or her own terms-is what makes it possible for life's potential to be fully utilized." Id.

33 Id. Similar criticism is expressed by political thinkers who seek an alternative to the individualistic premises they find central to the liberal thought. See Shlomo Avineri \& Avner de-Shalit, Introduction to COMMUNITARIANISM AND INDIVIDUALISM 1, 2 (Shlomo Avineri \& Avner de-Shalit eds., 1992) ("In liberal thought, Moralitat is a higher level of morality, tying in with the notion of the abstract and the universal individual who stands as an entity unto herself, the free and rational person...."). The underpinnings of the 
The Transformative Approach to mediation, according to Bush and Folger, aims to support disputants' moral growth through cultivating

communitarian alternative suggest that the individualist image of the self is ontologically false. Michael Sandel's notion of the "unencumbered self," for example, suggests that the liberal notion of the self is based on Kantian philosophy which finds the moral law in the subject, a subject capable of an autonomous will. Michael Sandel, The Procedural Republic and the Unencumbered Self, in COMMUNITARIANISM AND INDIVIDUALISM, supra note 33 , at 12,14 . That self is "understood as prior to and independent of purposes and ends." Id. at 18.

For further reading see MichaEL J. SANDEL, LIBERALISM AND THE LIMITS OF JUSTICE (1982), at 64-65. Alasdair MacIntyre criticizes liberalism for being rooted in a view which "view[s] man as having an essence which defines his true end." ALASDAIR MACINTYRE, AfTER VIRTUE: A STUDY IN MORAL THEORY 54 (1984). Charles Taylor seeks to rethink what he calls "political atomism," which inherited a vision of society "as in some sense constituted by individuals for the fulfillment of ends which were primarily individuals." Charles Taylor, Atomism, in SHLOMO AVINERI \& AVNER DE-Shalit, COMMUNITARISM AND INDIVIDUALISMS, supra note 33, at 29. Atomism, he explains, "affirms the self-sufficiency of man alone or, if you prefer, of the individual." Id. at 32. Christopher Lasch, in his best-selling book CULTURE OF NARCISSISM: AMERICAN LIFE IN AN AGE OF DIMINISHING EXPECTATIONS (1979), describes current American life as a time of narcissism in which the worldview emerging among Americans centers solely on the self and his individual survival as the sole good. A similar description is found in another best-selling book from the 1980's which criticized the individualistic worldview. ROBERT N. BEllaH ET aL., Habits OF THE HEART: INDIVIDUALISM AND COMMITMENT IN AMERICAN LIFE (1985). For further communitarian critique, see supra note 27 and accompanying text.

34 The narrative mediation model also takes as its starting point a critical stance towards the individualistic worldview and the problem-solving orientation to the mediation practice that stems from it. Winslade, Monk and Cotter write: "This way of thinking emphasizes the pleasure-seeking principle as a driving force in human decision making. It also directs us to focus on individual needs ahead of cultural, collective, or relational aspects of personhood. Conflict is understood to happen because individual needs are not being met." John Winslade, Gerald Monk \& Alison Cotter, A Narrative Approach to the Practice of Mediation, 14 Negotiation. J. 21, 22 (1998). For further critique of that approach as presented in the "narrative mediation" framework, see WINSLADE \& MONK, supra note 4, at 32-37. In this article I mainly focus on the transformative approach rather than on the narrative approach. The transformative approach makes the relational worldview foundational to its understanding of the mediation process, while within the narrative framework-in which the relational component is also important-the postmodern philosophy beget different emphases and view of the mediation process. When relating to the pragmatic, transformative, and the narrative approaches, Michal Alberstein writes: "Three intellectual worldviews, or cultures, underlie mediation: liberalism, critique of liberalism through relational ideas, and postmodernism." Michal Alberstein, Forms of Mediation and Law: Cultures of Dispute Resolution, 22 OHIO ST. J. ON DiSP. RESOL. 321, 328 (2007). 


\section{A BUDDHIST-ORIENTED VIEW OF NEGOTIATION AND MEDIATION}

constructive conflict interaction. Constructive conflict interaction demands acquiring a new, more complex view of what it means to be human, thus exceeding a one-dimensional and incomplete individualistic worldview. Moral growth, according to the alternative-relational worldview-that Bush and Folger present, includes recognition of the potential embedded in human nature to fulfill human freedom. ${ }^{35}$ Such recognition is based on different philosophical foundations than individualistic foundations. It is important to emphasize at this point that the alternative worldview Bush and Folger suggest does not exclude the values and goals of the individualistic worldview, but rather treats the individualistic worldview as only one dimension in a more complex framework. The relational worldview Bush and Folger present integrates both "self-interestedness," as emphasized by the individualistic worldview, and "responsiveness to others:" "human nature includes both the capacity for self-interestedness and the capacity for responsiveness to others." 36

In order to better understand their notion of responsiveness, claim Bush and Folger, it is essential to understand the governing premises of the relational worldview. Humans, according to the relational worldview as they see it, are both separated and connected: "Individuals are seen as both separate and connected, both individuated and similar. They are viewed as being to some degree autonomous, self-aware, and self-interested but also to some degree connected, sensitive, and responsive to others." 37

The relational worldview focuses on emphasizing how the differing aspects-either within the human beings or between human beings (e.g. human beings interacting in negotiation) - exist in mutual relatedness. The relational worldview aims at strengthening the ability to obtain and maintain a key balance between one-dimensional emphases-as Bush and Folger see it - of the individualistic worldview, and one-dimensional emphases of a worldview situated at the other end of the continuum-the organic worldview - which Bush and Folger present as a view that one-dimensionally emphasizes harmony, connectedness, and dependency. ${ }^{38}$

35 BUSH \& FOLGER, supra note 2, at 93.

36 Id. at 242.

${ }^{37} \mathrm{Id}$.

38 "Understood most simply, the valued end in this view is the survival and welfare of some collective entity-a family, tribe, community, society. Harmony is a way of describing the necessary condition for community well-being, because conflict can rip the entity apart. The value itself is really not harmony but community survival or welfare, to which harmony is instrumental. The good is understood as whatever the collective entity values and desires, and especially its 
The relational worldview favors neither the individualistic nor the organic worldview over the other, nor does it judge or dismiss the values, emphasized by each of these worldviews. Instead, the aim of the relational worldview is to create a more complex and integrated worldview in order to express seemingly contradictory values which each of these worldviews conveys in a balanced, and responsive, relational manner. Both the emphasis and the challenge are in creating that balance and the relatedness/responsiveness between the worldviews while recognizing that the relational values of that worldview are realized by doing just that: ${ }^{39}$

Indeed, the central feature of human nature, when perceived from the starting place of the transformation value, is neither individuality nor connectedness (and their associated qualities) but the element that relates the two in an integrated, whole human consciousness-the relational capacity. Human beings are thus simultaneously separate and connected, autonomous and linked, self-interested and self-transcending. Furthermore, they are capable of relating these dualities in an integrated wholeness that makes them capable of genuine goodness of conduct. ${ }^{40}$

The emphasis is on the relatedness of the individualistic and organic worldviews, as well as the "self-interestedness" and "connectedness" tendencies. The values of the relational worldview are manifested through a complex view, gained by the balanced integration of the two worldviews. Each of the worldviews - standing on its own and not in relation to the other worldview-is perceived as incomplete, one-dimensional, and unbalanced.

own survival and welfare." Id. at 240 . The organic/harmonistic worldview, according to Bush and Folger, subordinates the self to a collective entity, sacrificing one's own self-interests on the altar of "the collective good." The individual is expected to recognize that she is taking part in something larger than the self and to see that she is connected to others by taking part in the collective entity. She is expected to develop the capability to subjugate her personal needs to those of the collective through self-sacrifice and service. Human accomplishment is perceived in terms of transcending self-consciousness to a realization of something larger in which one is taking part. Bush and Folger write: "Starting from the value of harmony, the view of human nature is one that emphasizes connectedness, devotion, commonality, and selflessness." Id.

39 And therefore the analysis of the relations between the individualistic worldview and the organic worldview in the following pages may be also read as an alysis of relationship between two parties to a conflict, having two different views, an issue which the relational worldview sheds light on and helps clarify what transformation in a conflict management process means.

${ }^{40}$ BUSH \& FolgER, supra note 2, at 243. 


\section{A BUDDHIST-ORIENTED VIEW OF NEGOTIATION AND MEDIATION}

The transformative emphasis, according to Bush and Folger, is on the relatedness between "the one" worldview and "the other" worldview (the individualistic and the organic/harmonistic); the relatedness between "the one tendency" and "the other tendency" (self-interestedness and connectedness); and "the one" and "the other" party in mediation (party A and party B), who are to some degree separated (from each other) and to some degree connected. In order to allow connectedness and separateness to co-exist without subjugating one to the other, the relational worldview-as well as the transformative approach in practice-seeks to construct a relationship in which the values of both worldviews are fully expressed in a balanced manner, while keeping a "relational relationship" between them. On the one hand, they stand separately, but on the other hand they are at the same time connected; their separation and their connectedness relate to each other in a responsive manner.

Within the framework of the relational worldview it is no longer possible to speak of "two separate worldviews that are in a relationship," because such a statement embraces the governing premises of the individualistic worldview. At the same time, it is impossible to say that "the two worldviews are fused into a unified worldview which makes it impossible to separate the two," because then the organic worldview will be governing.

Similarly, on a human, interpersonal level, reaching transformation according to the relational worldview means cultivating a balanced relationship in which "relationality" as described above is practiced. For that to occur in a process of conflict management, disputants must manage their conflict in a manner that does not perceive the self solely according to the premises of the individualistic worldview, nor in a manner that perceives the self solely according to the premises of the organic worldview. From a relational perspective, we cannot continue to define the self as separate, nor say that "relationality and responsiveness are between two separate individuals"-an idea embedded within the framework of the individualistic worldview. ${ }^{41}$ According to the relational premises, as long as any of the "selves" is standing separately and not in a relational manner to other selves, the proceeding within the region of the conflict is one-dimensional. The perception of the self in accordance with the individualistic worldview lacks

41 Carol Gilligan, In a Different Voice: Psychological Theory and WOMEN'S DEVELOPMENT 151-56 (1982). Gilligan claims the attempts to read the relational premises from within the governing worldviews in developmental psychology, which identifies maturity with autonomy and separation, would not only preserve the outlook which sees relational premises as a developmental problem but also prevent from dealing with the complexities and paradoxes that that worldview brings forth. Id. 
the capability to create the needed balances to perform responsively and to manifest the relationality within the common space where human-beings relate.

Thus, we should read the emphases of the relational worldview from within a different framework, with different governing values than those of the individualistic worldview. It is difficult, therefore, to say that the governing values of the relational worldview are that "the two worldviews should be in a balanced relationship while showing mutual recognition between them," because such an utterance is derived from a perception that prioritizes the separation of the two worldviews from one another, and leads to a one-dimensional understanding of the relational perception. It may be that the analytic distinction between the two worldviews is meaningful for their analysis; however, in order to see things as they are, it is important to also see their connectedness and understand the significance of their relatedness for the perception of both their separateness and connectedness, as well as the partiality of the analytic description. There is a need to further construct relational philosophy and vocabulary. As Bush and Folger write, "[u]nlike the two worldviews described before, the Relational worldview cannot be linked to a familiar philosophy. Because it represents an outlook that is just emerging, it has no widely recognized character or "name" as yet." "42

I suggest, therefore, that there is a need for continued inquiry into the notion of the "self," and for understanding this notion in accordance with the relational emphases described above. Bush and Folger do not further develop the relational foundations in the second edition of The Promise of Mediation, or in any other subsequent literature. ${ }^{43}$ Further inquiry into the relational foundations is therefore necessary to clarify the relational worldview, including its philosophical underpinnings, and to explore the notions of "mutual recognition," "responsiveness," and "relationality" within a relational framework. This investigation must take place within a different framework than the individualistic climate, which permeates prevailing ways of thinking about human interaction. The next part will present the philosophical underpinnings of "relationality" as understood within the Buddhist worldview. In some respects these underpinnings resonate with those presented by Bush and Folger, and in some respects they offer a view of relationality which challenges the individualistic worldview and climate in

42 BUSH \& FOLGER, supra note 2, at 244.

${ }^{43}$ For further analysis of the manner in which the lack of further exploration of the relational underpinnings brings Bush and Folger to develop a practice that does not reside with the relational underpinnings as presented above, see Ran Kuttner, supra note 2. 


\section{A BUDDHIST-ORIENTED VIEW OF NEGOTIATION AND MEDIATION}

ways that the transformative approach to mediation does not suggest. This part will lead to a reexamination of both the theoretical bases to new practical emphases and the skills that the mediator and negotiator can apply.

\section{THE RELATIONAL UNDERPINNINGS OF THE BUDDHIST WORLDVIEW}

Like the Transformative Approach to Mediation, Buddhism aims to assist human transformation, not only in terms of one's actions, but in terms of one's mindset and governing underpinnings.

In his article, "The Contemplative Lawyer: On the Potential Contributions of Mindfulness Meditation to Law Students, Lawyers, and Their Clients," 44 Leonard L. Riskin emphasizes the advantages embedded in mindfulness for lawyers, or anyone who engages in negotiation or conflict resolution. A change in life quality occurs, Riskin suggests, as one reduces stress through the practice of cultivating "mindfulness" as understood in the Buddhist tradition. ${ }^{45}$ Riskin sees these stresses as an inevitable outcome of the mode and mindset nurtured throughout the legal education of law students, which is also common in lawyers' dispute resolution practice at large-an adversarial, distributive approach to disputes and negotiations. Riskin writes:

Although these mind-sets have great strengths, they also have drawbacks. They tend to promote egocentric behavior, excessive adversarialism, and a lack of balance between personal and professional aspects of life, which often lead to unhealthy levels of stress, to experiences of isolation, emptiness, and absence of meaning, and to the rendering of inadequate or inappropriate services. ${ }^{46}$

Riskin further claims that if viewed from a perspective of thorough transformation of the adversarial mindset, efforts made to change these common patterns were unsuccessful. The governing underpinning of the adversarial mindset, or in Riskin's terminology_- "The Lawyer's Standard Philosophical Map"-remains solid. 47 Efforts to construct alternative

${ }^{44}$ Leonard L. Riskin, The Contemplative Lawyer: On the Potential Contributions of Mindfulness Meditation to Law Students, Lawyers, and their Clients, 7 HARV. NEGOT. L. REV. 1 (2002).

$451 d$. at $10-13$.

$46 \mathrm{Id}$. at 8.

${ }^{47}$ For further reading on "The Lawyers Standard Philosophical Map" see Leonard Riskin, Mediation and Lawyers, 43 OHIO ST. L. J. 29, 43-48 (1982). 
underpinnings and create meaningful change merely influence this map's margins. While describing this governing mindset, Riskin writes:

The traditional mind-set provides a constricted vision of legal problems and human relations that rests on separation and autonomy, on rights and rules. Thus, it contrasts with mind-sets grounded on connection, relationship, and duty. And mind-sets can affect a lawyer's understanding and performance in virtually any task. ${ }^{48}$

The focus of this article is the philosophical foundations of the Buddhist worldview, which are relational and which Buddhist practice helps realize. Clarifying these foundations allows a clearer understanding of the Buddhist view of transformation and its relevance to the conflict situations. The Buddhist view of conflict involves transformation beyond improving the skill-set of those engaged in negotiations and conflict management procedures. Understanding these philosophical foundations may assist the mediator or negotiator in emphasizing the centrality of the relational aspect and may assist in advancing the project of transformation of individualistic worldview to relational worldview.

However, to see the goal of Buddhist practice solely as the achievement of stress reduction and improved lawyering skills misses the transformative potential of this worldview. Buddhism aims to release the practitioner from the illusory way in which the "self" is perceived in everyday life, and cultivate a transformation of one's fundamental understanding of the self through the realization of the relational and responsive nature of all things, a premise central to the Buddhist worldview. Within the framework of the Buddhist worldview, relationality has a foundational role, as Izutsu explains: "Buddhism in this respect is ontologically a system based upon the category of relation, in contrast to, say, the Platonic-Aristotelian system which is based on the category of substantia." 49

While the self is commonly grasped to be an unchanging, substantial, separate entity, independent from the web of relations in which it takes part, and according to the Buddhist worldview this perception of the self is an illusion which creates human suffering and dis-ease (duhkha) ${ }^{50}$ Moreover,

48 Riskin, supra note 44 , at 16.

49 Toshiniko Izutsu, Toward a Philosophy of Zen Buddhism 23 (Prajna Press 1982) (1977).

50 I will use both the terms "suffering" and "dis-ease," as the original Buddhist term-Duhkha - which is commonly translated to the former, can also be translated to the latter. I would prefer to address the latter, as although conflicting situations may not 
this illusion-according to the Buddhist worldview-relates not only to the perception of human beings as possessing a substantial and independent "self," but to the perception of any object as a separate, self-substantive entity. Such a mindset is a partial and insufficient understanding of reality, described in the Buddhist framework as ignorance (avidya). Buddhist practice aims to enable the practitioner to transform avidya into a realization of one's true nature, realization described as wisdom (prajna).

A key concept in the Buddhist worldview is "dependent co-arising" (pratitiyasamutpada) ${ }^{51}$ According to the principle of dependent co-arising, any given situation is a set of connections and relations in which separate entities arise, which through a process of abstraction, we grasp as having the characteristics of continuous separate substances. Every "thing," every apparent object we seem to grasp as standing on its own, separate from other objects, is not, according to the Buddhist view, as such. The idea that objects are defined as having their own essence, substance, and unique characteristics that will never change, is perceived by Buddhist philosophy as an abstraction derived from the human need to arrange the world and create what Buddhism sees as an illusion. ${ }^{52}$ Seeing entities as continuous separate substances results from observing the situation from outside, abstracting from the process of dependent co-arising as it occurs. Thus, we create notions of entities that we then perceive to be separate from their arising, possessing a substantial and permanent inner-nature with which "they" then

always be perceived as "suffering," they can in most cases be designated as discomfort and stress that apply to broader human situations (e.g., when in interpersonal conflict), which I choose to call "dis-ease." See WalPOla RahUla, WHAT THE BUdDHA TaUghT 17 (1959).

51 This concept is so central that the Buddha claims that whoever understands it understands the whole of his teaching (or Dharma); whoever does not understand dependent co-arising, continues the Buddha, will not be able to understand the Dharma. Izutsu writes:

We may do well to recall at this point that Buddhism in general stands philosophically on the concept of pratityasamutpada, i.e. the idea that everything comes into being and exists as what it is by virtue of the infinite number of relations it bears to other things, each one of these 'other things' owing again its seemingly self-subsistent existence to other things.

IZUTSU, supra note 39, at 23.

52 An elaboration on the psychological mechanism by which that illusion is formed according to the Buddhist worldview demands a separate article. 
enter a process of interaction with another-similarly substantial and permanent-entity. ${ }^{53}$

The Aristotelian framework, the foundation of Western thought and logic, is a philosophical system based on the category of the "substance," seeing each object as having an inner core, an ontological entity that expresses its essential characteristics. ${ }^{54}$ Knowing an object's essence, according to Aristotelian thought, entails exposing its self-identity, and its unchanging, inherent, and essential characteristics. These characteristics are not affected by, and are thus independent of, outside variables such as the characteristics of other objects. Knowing the object, according to the Western view, means knowing that these independent, untouched, and unchanged essential characteristics that are not affected by its interactions with other objects, and a superficial perception of the object would focus only on the dependent and changing variables outside of the object's essence. ${ }^{55}$ The Aristotelian worldview is an essentialist worldview:

[T] he essentialist position sees on both the 'subjective' and 'objective' sides of the $s \rightarrow$ o type of situation self-subsistent substances, the boundaries of each of which are inalterably fixed and determined by its "essence". Here $o$, say, an apple, is a self-subsistent substance with a more or less strictly delimited ontological sphere, the delimitation being supplied by its own 'essence,' i.e. apple-ness. In the same manner, the ego which, as the subject,

${ }^{53}$ For example, "Mr. X," a separately defined subject, who interacts with "Mr. Y." This applies to every "entity," perceived as such, e.g. "mountains," "trees" etc.

54 This is not to imply a unitary "Western" philosophy. Throughout the history of ideas in Western culture, diverse frameworks suggested views different in their tenets from those laid by Aristotle. However, in here I refer to Aristotelian tenets and logic as governing Western tenets, dominant in the Western thought from Aristotle onwards. In addition, it is not only "Western", as the Buddha's teachings come as criticism of the governing philosophical and spiritual tenets of his time in "the East", i.e. the Indian Upanishad and others, as these philosophies suffer from similar confusion, referring to the true inner nature of things.

${ }^{55}$ René Descartes, in his essay, Meditations on First Philosophy, which is considered to be one of the foundational essays of modernity and of the enlightenment era, claims that knowledge is obtained when an entity is perceived in its distinctness: "Everything that we clearly and distinctly understand is true in a way which corresponds exactly to our understanding of it." See René Descartes, Meditations on First Philosophy, in The Philosophical Writings OF DesCartes: Volume 212 (John Cottingham et al. trans., Cambridge Univ. Press 1984) (1641). According to Descartes, clear knowledge goes together with the distinctiveness of the entity known. Id. 


\section{A BUDDHIST-ORIENTED VIEW OF NEGOTIATION AND MEDIATION}

perceives the apple is an equally self-subsistent substance furnished with an "essence", which, in this case, happens to be I-ness. 56

The Buddhist worldview, on the other hand, offers different philosophical foundations:

The position of pratityasamutpada stands definitely against this view. Such a view, Buddhism asserts, does nothing other than reflect the phenomenal surface of reality. According to the Buddhist view, it is not the case that there does exist in the external world a substance with a certain number of qualities, called 'apple.' The truth is rather that Something phenomenally appears to the subject as an "apple." The phenomenal appearance of the 'apple' as an 'apple' depends upon a certain positive attitude on the part of the subject. Conversely, however, the very fact that 'apple' phenomenally appears as such to his eyes, establishes man as the perceiving ego, the subject of cognition. ${ }^{57}$

The idea of a "thing," an entity or object with internal unchanging characteristics or conditions, is an illusion according to the Buddhist worldview. First, there are no unconditional entities: all "things" are causally dependent, or rather-dependently co-arise. ${ }^{58}$ Second, every "thing" is in a never-ending, ceaseless motion, and nothing is permanent or fixed. 59 That includes all the characteristics that according to the essentialist worldview, are of permanent nature. The whole existence is a continuous process, an endless flow of energy, while "we, ordinary human beings, slice this flow into pieces, freeze them into static entities, give them names, classify and characterize them, and ascribe to them characteristics in space and time."60

The process of abstraction and of grasping "the object"-or "the party" in a negotiation or a mediation setting - in such a manner, not only leads to shaping and grasping onto the object perceived and its definition, but it reflects on the perceiver as well. The perceiver is also shaped and seen as a separate firm entity, a self with similar characteristics. According to the

56 IZUTSU, supra note 49, at 23.

${ }^{57} I d$. at $23-24$.

58 That includes the concept of "dependent co-arising" itself. Understanding, or rather realization, means understanding through the expression of this notion in reality.

${ }^{59}$ In Western philosophy Heraclitus, the $5^{\text {th }}$ century B.C. Greek philosopher is known for holding a similar view. He claimed that everything is changing and flowing ("panta rei"). However, his view was not accepted. See Stanford Encyclopedia of Philosophy, http://plato.stanford.edu/entries/heraclitus/ (last visited April 4, 2010).

60 LYDIA ARAN, BUDDHISM 29 (Ran Kuttner trans., 1993). 
Buddhist worldview, realizing the true nature of things demands the realization of relationality - a realization that all the conditioned things are always dependent upon other things, as well as the realization of the law of impermanence (anitya). The Aristotelian worldview would respond to that assertion by stating that "all the permanent things are unconditioned." The Aristotelian assertion is not compatible with the Buddhist philosophy, as there are neither "unconditioned things" nor "permanent things."

With these notions as foundations, the Buddha's teaching of pratityasamutpada, dependent co-arising, can be clarified:

When this is, that is;

This arising, that arises;

When this is not, that is not;

This ceasing, that ceases. ${ }^{61}$

This is not a description of causality in its common sense, according to which the existence of one independent and separate thing leads to the existence of another independent and separate thing. Instead, this teaching explains that the existence of one thing (this) beside the existence of another (that), entails their co-arising into "this" and "that." Without mutual existence and relatedness, it is impossible to describe or apprehend things as such ("this" and "that"; for example, I [this], and the work I am engaged in right now [that], or the person who talks to me [this] and myself [that]). There is mutual relationality between things, and only within the specific common space of that relationality and the manner in which the relatedness is taking place at that particular moment, can they be described as "this" and "that." When one does not exist within that space ("this"), the other ("that") does not exist, as its existence is mutually dependent. When one thing ceases to exist as such ("this") within a given space, the other no longer exists as such ("that") within that same space. This should not lead to nihilistic conclusions of dependency, which would imply that the cessation of one ("this") leads to the annihilation of the other ("that"). Just as "that" does not arise as a result of "this" arising in a causal manner as commonly understood, "that" does not cease to exist as a result of "this" ceasing to exist. Neither of them has an existence on its own; rather, they co-arise simultaneously, being what they are: the specific impermanent "this" and "that" that will no longer be as such when the situation and the web of relations change. "They" are

61 Assutava Sutta (SN 12.61), in Walpola RahUla, What the BUddha TAUGhT, supra note 50, at 53 . 


\section{A BUDDHIST-ORIENTED VIEW OF NEGOTIATION AND MEDIATION}

empty of self-substantial existence-of inner, continuous, nature-and therefore they cannot become what they already are. "They" will co-arise to whatever relationally co-arises in the common space of the "this" and "that"- understood as such only in the particular web of relations.

This explanation applies not only to objects, but also to the self, the primary investigation of the Buddhist practice, which very much like the Socratic imperative tries to address the imperative "know thy self." The Buddhist tradition, however, provides a different answer than the Socratic tradition and a different manner of investigation. Indeed, Buddhism sees the assumption of an existing continuous "self" as an illusion. As Biderman writes: "The personality of the human being is defined anew in each moment of its existence by the set of conditions that create it in that moment." 62 This may invite one of two conclusions: (1) that the self cannot be grasped as such because of the limitations of human intellect, and therefore a profound realization of the true self calls for irrational activity which would exceed these limits; or (2) because it is impossible to speak of the self as continuous and unchanging, all that is left is to deal with is its appearances, momentary and discontinuous, lacking regularity, inner logic, while assuming chaos and giving up on the possibility of order. However, both conclusions still presuppose existence of the "self," 63 even as an entity that all that we can say of it is that it is non-existent. ${ }^{64}$

62 See SHLOMO BEDERMAN, EARLY BUDDHISM 82 (1995).

${ }^{63}$ Both are nihilistic in nature, while the Buddhist view is not nihilistic. See WALPOLA RAHULA, WHAT THE BUDDHA TAUGHT, supra note 50, at 66 .

${ }^{64} \mathrm{Id}$. ("According to the Buddha's teaching, it is as wrong to hold the opinion 'I have no self' (which is the annihilationist theory) as to hold the opinion 'I have self' (which is the externalist theory), because both are fetters, both arising out of the false idea "I AM."').

In order to understand the Buddhist departure from nihilistic conclusions, it is important to better understand the notion of emptiness (sunyata) mentioned above, and the way in which it helps avoid the conclusion that the self is non-existent. The allegation that "nothing exists as an independent substantial entity" may lead to the conclusion that things are empty of inner nature, of essence. Therefore, it is concluded, things do exist, but with no firm form as finite, separate entities. "They" are empty, and this emptiness leads to the inability to define them, to grasp them as having a determinate form: "They" are empty of the characteristics of finitude, substantivity, separateness. However, such conclusion is only a partial conclusion, for it still contains the presupposition that things exist, as "things"--even if empty of inner essence. It is important to realize (existentially, not as an intellectual exercise) that "they" are also empty of the conclusion invited by their emptiness: the conclusion that "they" exist, even as empty of self, of having a form. 
The realization of emptiness is simultaneously the realization of dependent co-arising. "Things" are ungraspable in themselves, not as existent nor as non-existent, neither as separate nor as connected, but seen in a different, middle way: dependently co-arising. Their real nature does not exist, but also does not "not-exist;" "real nature" is an empty notion, empty in the strong sense of the word, because not only do they lack "real nature," they also lack self-existence which is capable of lacking "real nature."

The same applies to our use of concepts. Once we realize that concepts also dependently co-arise, we realize that objectification and characterization do not apply to objects separate from other objects with which they interact or from the process of dependent co-arising with the action of characterization itself. Thomas Kasulis writes: "Although the world itself is not illusory, our characterizations of the world are fundamentally selfcontradictory, relative, and tentative. Without the insight of prajñ $\tilde{a}$, we run the risk of becoming attached to our characterizations, of thinking of them as absolutes..."65

Kasulis emphasizes the importance of wisdom (prajna) in refraining from attachment (upadana) to the things we perceive as self-substantive objects, and to the concepts we use to describe these objects. Attachment of this kind means ascribing to a status of self-substantive, separate existence, without regard to the process of dependent co-arising, the law of impermanence or the ceaseless process of change, thus falling back to an essentialist view and to ignorance (Avidya) ${ }^{66}$ In a state of Avidya, we lack

65 T.P. KASULIS, ZEN ACTION ZEN PERSON 25 (1981); see also Nagarjuna, Mulamadhyamakakarika, in THE FUNDAMENTAL WISDOM OF THE MIDDLE WAY: NAGARJUNA's MUlamadHYAmaKaRIKA 48-49 (Jay L. Garfield trans., Oxford Univ. Press 1995) ("Action and misery having ceased, there is nirvana. Action and misery come from conceptual thought. This comes from mental fabrication. Fabrication ceases through emptiness... What language expresses is nonexistent. The sphere of thought is nonexistent. Unarisen and unceased, Like nirvana, Is the nature of things.").

${ }^{66}$ Goenka, while teaching Vipassana meditation, asserts the following:

[G]reat attachment is to the 'I,' the ego, the image we have of ourselves. For each of us, the ' $I$ ' is the most important person in the world... we all instinctively try to arrange the world according to our liking, seeking to attract the pleasant and to repel the unpleasant. But none of us is alone in the world; one "I" is bound to come into conflict with another. The pattern each seeks to create is disturbed by the magnetic field of others ... The result can only be unhappiness, suffering.

William HaRT, The ART of Living: Vipassana Meditation as Taught by S.N. GOENKA 46 (1982). Suffering and unhappiness is caused by the attachment to the "I" who seeks to create a pattern that is independent of an assumingly-disruptive field of "others." Id. Goenka continues: 


\section{A BUDDHIST-ORIENTED VIEW OF NEGOTIATION AND MEDIATION}

wisdom (Prajna), i.e. the realization of emptiness, dependent co-arising, and impermanence. ${ }^{67}$

The notions of relatedness and responsiveness acquire new, extended meaning. Without responsiveness and relatedness, the parties are ignorantly perceived to be standing on their own-substantive, unified, and independent. However, realizing the full meaning of these notions demands a radical change in perception. Any attempt to describe the essence of a thing which supposedly exists beyond the continuous flow of dependent co-arising is, according to the Buddhist philosophy, an illusion based on ignorance. The blossoming of the flowers, as explained by Dogen, is the spring. 68 "Spring" receives its form only within the context and in relation to the blossom. The use of the concept "spring" as exists behind, without the relation to the blossoming of the flowers, is an abstraction and an illusion.

Nor do we limit attachment to the 'I': we extend it to 'mine,' whatever belongs to us. We each develop great attachment to what we possess, because it is associated with us, it supports the image of ' $I$ ' . . . And attachment extends still further-to our views and our beliefs. No matter what their actual content may be, no matter whether they are right or wrong, if we are attached to them they will certainly make us unhappy. We are each convinced that our own views and traditions are the best and become very upset whenever we hear them criticized... It is futile to argue which view is correct; more beneficial would be to set aside any preconceived notions and to try and see reality.

Id. at 46. Seeing reality, realizing things as they are (tathata), means realizing the emptiness of the firm and separate "self" or of any other "thing," realizing impermanence and dependent co-arising instead of holding to pre-suppositions regarding an independent, firm "self" and independent, firm "positions." To paraphrase Immanuel Kant, it may be said that reality, the "thing in itself"-which is not open according to Kant to human grasping (see infra note 71 and accompanying text)--should be seen as "the thing in its non-self," open for human realization when realized as such.

${ }^{67}$ KASULIS, supra note 65 , at 25-26 ("Zen [Buddhism] maintains that no characterization of the person ever captures its full reality: a description only highlights one aspect to the exclusion of others... human beings can delude themselves by identifying with particular descriptions. Dogs do not think of themselves as collies, spaniels, or even as dogs. Only humans reduce themselves to communists or capitalists, blacks or whites.") Kasulis writes on Zen Buddhism, a current within Buddhism, but for our need here, it is a description of the Buddhist worldview. Wherever the differences and inner distinctions between various currents within the Buddhist tradition may affect the understanding of the premises presented here, these differences will be noted and explored.

$68 \mathrm{See}$ opening quotation to this article, as found in JACOB RAZ, ZEN BUDDHISM: PHILOSOPHY AND ESTHETICS 97 (2007) (Ran Kuttner, trans.). 
In a similar fashion, the view that sees "the person" in a generalized way as existing beyond, or situated behind, the events and processes of dependent co-arising, is an illusive view that presupposes a mind that contains that activity in a large container (i.e. the personality). The goal is to transform such a view to a direct experience of things as they are, without the need to withdraw to such generalization. Izutsu writes, "it is not enough that an apple should not be seen as an apple; it should not be seen as anything whatsoever. Positively stated, an apple should be seen without any delimitation. It must be seen in its indetermination." 69

It is not "the person" who arrives at a meeting with "the object" which should be the focus of our analysis according to the Buddhist worldview, rather "the person" is perceived anew. This is an important point, as it stresses that the investigation is not individualistically oriented; rather, wisdom can be attained only through cultivating awareness to the ongoing dependent co-arising nature of impermanent situations. The context of the meeting between two individuals in negotiation has the potency to allow such realization, while the personal practice of meditation is grasped in the Western individualistic climate as a performance of the "self." Awareness is then turned to that self. The presence of a conflict and the meeting where negotiation takes place to address the conflict is an excellent ground for reexamining of the set of relations-both on the level of the content, the issue at hand, and on a deeper level of realization. It may allow realization of the common space where humans relate in the deepest sense of relatedness and a transformation of some governing underpinnings accordingly. The idea of "conflict as potential for moral growth" gains a new, wider meaning: conflict has the potential to reveal the illusory nature of perceiving individuals as self-existing, separate, and independent entities that interact with other self-existing, separate, and independent entities. This allows the individual to realize the relationality of the encounter as revealed through the web of relations that arise in the common-space within which the situation unfolds. ${ }^{70}$

69 IZUTSU, supra note 49 , at 14.

70 The clear distinction between the subject and its objects which lies at the basis of the Aristotelian logic and Western ontology at large, and of the individualistic worldview in particular, is transformed. Much of twentieth century Western philosophy-as presented in the first part of this paper-is focused on overcoming these oppositions (subject-object, I-you ... ), while the Buddhist worldview and philosophy has no such foundations in the first place. Rollo May, in a somewhat generalizing way, writes: "Eastern thought never suffered the radical split between subject and object that has characterized Western thought, and this dichotomy is exactly what existentialism seeks to 


\section{A BUDDHIST-ORIENTED VIEW OF NEGOTIATION AND MEDIATION}

As the philosophical foundations of the Buddhist worldview have utterly different foundations than the Aristotelian and Cartesian philosophies, Buddhist foundations possess a genuine outlook on some of the foundational dichotomies: for example, "subject"-“object," "man"-“world," "man"-_man." As part of its differently-founded view, the Buddhist worldview also recognizes the difficulties common sense- "Western" as well as "Eastern"meets when the underpinnings of the Buddhist philosophy are laid out without the mental activity and practice that are meant to assist the practitioner transform illusive mindsets to realization of these underpinnings through experience.

Contrary to a human being's sense of confined and bounded stance(con)fronting the world, (con)fronting creation, (con)fronting GodBuddhism offers a practice that may allow transformation of that fronting existential stance to seeing things as they are (tathata) in constant change and dependent co-arising. Immanuel Kant deservedly expressed the Western view of limited human perspective by describing that "the things in themselves," the true nature of the objects, are beyond the reach of human perception. ${ }^{71}$ Buddhist philosophy, assisted by the practice of meditation and the realization of emptiness and dependent co-arising, acknowledges the possibility of transforming ignorance (avidya) into wisdom (prajna), such as the possibility of realizing things as they are, in their "suchness" (tathata). This does not mean "seeing the objects as they really are," in their true nature but seeing the situation while recognizing moment-to-moment that "things" are dependently co-arising, empty of substantive-self whose "true nature" needs to be sought.

[W] hat is meant thereby in Zen Buddhism is a dynamic field of power in its entirety and wholeness, an entire field which is neither exclusively subjective nor exclusively objective, but comprehending both the subject and the object in a peculiar state prior to its being bifurcated into these two terms. ${ }^{72}$

The illusion of the true nature of the "thing in itself" is replaced by the realization that separate objects or selves can be found the the process of dependent co-arising. Then, the situation is revealed, as directly experienced.

overcome." Rollo MAY, THE Discovery OF BEING: WrItINGS IN Existential PSYCHOLOGY 59 (1983).

${ }^{71}$ Immanuel Kant, Critique Of Pure Reason 112 (Cambridge Univ. Press, 2000) (1781).

72 MASAO ABE, ZEN AND WeSTERN THOUght 24-25 (1985) (emphasis added). 
While mindful of dependent co-arising, realizing impermanence and the empty nature of "the situation"- - things are realized in their suchness, totally inter-dependent, dependent on the process of relational co-arising in the common space.

The Buddhist worldview is different from the relational foundations described by Bush and Folger, who place the individual at the center of their investigation, describing "him" as being both separated from and connected to other individuals. Bush and Folger, I suggest, do not go far enough in shifting away from the individualistic underpinnings they wish to transform. Kasulis, while relating to the Japanese culture, writes:

[T]o see someone as an "individual" (kojin) is to see that person as one object among many, an individual extracted from the context of the group for purposes of enumeration. This description clearly lacks the force of the term individual conveyed in Western languages... but when they see someone as a "human being" (ningen), they see that person in a context. From the Japanese point of view, the person is not primarily an individual subsequently placed within the world. Rather [...] the person is always in a context, in a necessary relationship with what is around him or her. ${ }^{73}$

I suggest that the Buddhist worldview offers a relational perspective which is different from Bush and Folger's relational view of human nature. "Things" do not stand in separation and connectedness to each other, as the Aristotelian-based worldview interprets the notion of relationality. Rather, things mutually and dependently co-arise within the common space-the situation. Both ontologically and epistemologically, relationality is not secondary to separation. Kasulis continues:

There is an important distinction to be made between the way Westerners and Japanese see the function of language. Suppose we represent interpersonal communication as $a R b$, where $a$ and $b$ are persons and $\mathrm{R}$ is the linguistic medium through which they communicate. The Western view typically regards $a$ and $b$ as two transmitters, each emitting signals to be received and interpreted by the other. In English, for example, we speak of language as a bridge spanning the gap between $I$ and you. The isolated $a$ and $b$ together create an $R$ so that communication can take place. In Japan, however, the event is viewed quite differently: the $R$ is the given out of which $a$ and $b$ take their shape. ${ }^{74}$

\footnotetext{
${ }^{73}$ KaSULIS, supra note 65 , at 6.

${ }^{74} \mathrm{Id}$. at 7.
} 
The bridge, according to this view, is to be constructed differently while realizing the Buddhist premises of not mediating between $a$ and $b$ as within the Aristotelian tradition but through the realization of the manner in which they take their shape.

The Buddhist framework gives new meaning to the central values that Bush and Folger espouse: responsiveness, recognition, and relatedness as foundational qualities of the Buddhist worldview. Bush and Folger's cultivation and realization support a relational, existential mindset. Bush and Folger's view is not a theoretical stance implemented by an individual in practice, but a realization cultivated in the common-space, through awareness to emptiness, impermanence, and dependent co-arising.

Buddhism, as mentioned above, is not an abstract theory, but a means for the transformation of the suffering and dis-ease (duhkha) caused by the illusive perception of the separate, independent "self" and the attachment to such substantial entities. Within the context of mediation/integrative negotiation, Buddhism helps transform parties' dis-ease, where they suffer due to their attachment to firm, separate, and independent "selves," taking sides and unaware of the centrality of relationality in the inter-personal, conflictual common space.

Using any of the techniques developed in the Buddhist tradition to transform human ignorance and dis-ease, the practitioner of meditation or other practices transforms suffering by cultivating relational awareness. The transformation Bush and Folger seek during the mediation process has similar aims: to aid disputants transform the dis-ease caused by the dispute through cultivating relational awareness. ${ }^{75}$ The Buddhist worldview and practice, however, can help clarify the relationality both on the "worldview" level and on the practical level. The Buddhist worldview is primarily a practical framework that aims at helping the practitioner transform her essentialist "ignorance" into relational awareness on the experiential level. Thus, the Buddhist worldview offers a new understanding and realization of the notion of transformation from adversity to cooperation. This new understanding may be relevant, not just to the Transformative or Narrative approaches to mediation. Indeed, the following section will demonstrate how the philosophical foundations and transformation offered by the Buddhist worldview coincide with the basic motivations and central values found in integrative negotiation literature. The following section may also offer valuable insight concerning "changing the game" from an adversarial

${ }^{75}$ BUSH \& FOLGER, supra note 2, at 243. 
mindset and derived distributive bargaining, to a truly collaborative mindset and an integrative style of negotiation.

\section{UNDERSTANDING INTEGRATIVE NEGOTIATION AS A RELATIONAL Practice Through Buddhist PHILOSOPHY}

In the remaining portion of this paper, I examine some basic premises of "integrative negotiation," which theoreticians and practitioners long have presented as an alternative to the "adversarial" or "competitive" negotiation mindset and techniques. With the help of the Buddhist philosophy and an understanding of the "relational worldview" that stems from that philosophy, this section explores the possibilities to give new meaning to some governing premises of integrative negotiation and suggest new possibilities for helping disputants transform the dis-ease caused by an adversarial mindset. This is not meant to claim that the thinkers whose work is reviewed in this section hold similar tenets to the relational worldview discussed thus far. Some differences exist between thinkers who write from a pragmatic standpoint and hold a different philosophical "worldview" and mediation or negotiation "story," and thinkers who challenge the pragmatic standpoint and the succeeding problem-solving orientation.

The intellectual worldview that underlies the pragmatic school is the individualistic or liberal worldview, to which the relational worldview offers an alternative. ${ }^{76}$ It is a mutual gain, interest-based approach to negotiation, based on what Bush and Folger called "the satisfaction story," and is different from the various "transformation stories" that the transformative approach to mediation or the Buddhist worldview hold. ${ }^{77}$ However, the presentation of prominent pragmatic thinkers shows-without suggesting that they hold the Buddhist underpinnings and without enforcing relational underpinnings or transformation stories on these writings - that these works hold tendencies and motivations that resonate with some of the values presented by Buddhist philosophy. If we accept the above premise, I suggest that a process of cross-fertilization is possible, in which the Buddhist foundations may help to "offer a new reading"78 of basic concepts that the pragmatic literature of integrative negotiation and mediation present.

76 Alberstein, supra note 34, at 322.

77 For further reading on the "satisfaction story" described by Bush and Folger, see BUSH \& FOLGER, supra note 1, at 16-18.

78 Alberstein, supra note 34, at 323. 


\section{A BUDDHIST-ORIENTED VIEW OF NEGOTIATION AND MEDIATION}

The motivation to set the terms for overcoming suffering and dis-ease is foundational in both the Buddhist worldview and the movement seeking to bring attention to cooperation and integration as appropriate alternative modes of dispute resolution. Mnookin, Peppet, and Tulumello, describing common occurrences when faced with a conflict, write:

When faced with conflict, we tend to either advocate forcefully-often too forcefully - our own view or focus on the other side's view.... We each assert our own story and listen to the other side only for the purpose of constructing a "Yes, but" response. We cycle through argument and counter-argument, never demonstrating understanding or really communicating very effectively. ... Either I can listen and try to understand your point of view, or I can assert my own.... Once I understand your view-and show you I understand-holding on to my own perspective will become too difficult. After all, if I agreed with your view I wouldn't have mine! ... Our views are just fundamentally different. If $I$ advocate for mine, I can't also advocate for yours. It's one or the other, not both. ${ }^{79}$

When the parties arrive at the negotiation table with a distributive mindset, their inclination would be to present firm and secured positions, clear and distinctive, clarified in separation, to which they firmly cling. ${ }^{80}$ Positions represent an uncompromised manifestation of how individuals perceive themselves, the situation, and what they want to obtain for themselves. ${ }^{81}$ These positions are shaped in opposition to the other parties'

79 Robert H. MNOOKIN, SCOTT R. PePpet \& ANDREW S. Tulumello, Beyond WINNING: NEgotiating to CREATE VALUE IN DEALS AND DisPutes 50 (2000).

${ }^{80}$ Lee Ross \& Constance Stillinger, Barriers to Conflict Resolution, 7 NEGotiation. J. 389, 395 (2001) (describing as cognitive dissonance about the past where "past justifications for rejecting advantageous terms-justifications offered to oneself, as well as to one's peers and critics-serve to increase the psychic and social costs of accepting those terms now"). Alberstein calls it a "dissonance arising from the past." Michal Alberstein, On Biases, Limited Rationality and Opposing Voices: Cultures of Negotiation and of Law, in MISHPATIM AL AHAVA 657 (Orna Ben-Nafhi \& Hanna Nave, eds.) (Ran Kuttner, trans.). This dissonance also affects one's perception of the future, as he develops unrealistic hopes about the future to which he clings through his demands.

${ }^{81}$ Kahneman and Tversky claim that "people typically rely on the representativeness heuristic, in which probabilities are evaluated by the degree to which $A$ is representative of B, that is, by the degree to which A resembles B." Daniel Kahneman \& Amos Tversky, Judgment Under Uncertainty, 185 SCIENCE: HeURISTICS AND BASICS 1124, 1124 (1974). When attached to a certain perception of oneself, one's acts and judgments ought to be consistent with that perception as they represent oneself. It also affects the 
positions and to what the other parties want for themselves. ${ }^{82}$ They represent a binary either/or state of mind. 83 By focusing on end results, the parties narrow the realm of discussion, limiting the possibility of adjusting 84 or opening up a discussion that would take into account perspectives and options that are not consistent with their presented positions ${ }^{85}$ or that would alleviate any uncertainty. ${ }^{86}$ Parties feel committed to their positions ${ }^{87}$ and make their judgments in accordance with their belief structure, thus reinforcing their judgments in a biased, egocentric manner consistent with their perception of self. ${ }^{88}$ With that commitment comes a great fear of loss,

manner one predicts future outcome, based on the manner in which it should be a valid prediction, consistent with what is being represented. Id. at 1126 . Mnookin argues that on a strategic level, what may be rational for a self-interested party who wishes to maximize one's own gains, is not necessarily so if enlarging the pie and creating value is sought. Robert H. Mnookin, Why Negotiations Fail: An Exploration of the Barriers to the Resolution of Conflict, 8 OHIO ST. J. ON DISP. RESOL. 235, 241 (1993).

82 What's good for "them," "is obviously not good for "us." Id. at 246. Moreover, parties in these cases tend to react to other parties' offers in a "devaluative" manner, i.e. a proposal can look less desirable than it otherwise would, merely because a counterpart offered it. Id.; see also Russell Korobkin \& Chris Guthrie, Heuristics and Biases at the Bargaining Table, 87 MARQ. L. REV. 795, 804 (2004); Lee Ross, Reactive Devaluation in Negotiation and Conflict Resolution, in KENNETH ARROW ET AL., BARRIERS TO CONFLICT RESOLUTION 26 (1995).

83 See Bernard Mayer, The Dynamics of Conflict Resolution: A PRACTITIONER's GUIDE (2000).

84 When anchoring in a certain judgment, "experimental evidence indicates that people often fail to adjust sufficiently away from the initial 'anchor."' Korobkin \& Guthrie, supra note 82, at 799; see also MAX H. BAZERMAN \& MARGARET A. NEALE. Negotiating Rationally 23-30 (1992); Max H. Bazerman \& Margaret A. Neale, The Role of Fairness Considerations and Relationships in a Judgmental Perspective of Negotiation, in KENNETH ARROW ET AL., supra note 82, at 86.

85 When one arrives with certain predictions, highly consistent patterns are most often observed as "people tend to have great confidence in predictions based on redundant input variables," i.e., with input that correlates with their prediction and with the entity behind it that that prediction represents. Kahneman \& Tversky, supra note 81 , at 1126.

86 See ALBERSTEIN, supra note 80, at 657 (Ran Kuttner, trans.).

87 See Max H. Bazerman \& Katie Shonk, The Decision Perspective in Negotiation, in THE HANDBOOK OF DisPUTE Resolution 52, 58 (Michael Moffit \& Robert Bordone, eds. 2006). As time moves on, parties to the negotiation feel that they have too much time, money, and ego invested and backing off becomes less and less of an option. See BAZERMAN \& NEALE, supra note 84.

88 "People tend to arrive at judgments of what is fair or right that are biased in the direction of their own self-interests." Linda Babcock \& George Loewenstein, Explaining 
which overtakes the possibility of creating value ${ }^{89}$ and creates difficulty in adjusting to new situations. ${ }^{90}$.

These tendencies can be described in terms of entrenchment in a firm, fixed, separated self, manifested by similarly characterized positions. A position poses; it lacks movement and thus differs fundamentally from the notion of impermanence. A position also represents an independent standingpoint. When in a conflict, one tends to entrench within the self, manifested by the attachment of "a party" to firm positions that one brings to the table, refusing to re-examine them, as well as oneself, within the dependent coarising common-dialogic-space. It also involves the cognitive biases described above and an avoidance of the realization that only within that common-space and through dialogue can the separate self be fully realized, as well as an entire picture of one's needs and interests. When withdrawing from and ignoring the common dialogic, relational, space and entrenching in the fixed, seemingly independent, positional self, ignorance (avidya) of the process of dependent co-arising is taking the place of wisdom as understood within the Buddhist framework. Wisdom that is consistent with a relational integrative mode of interaction. A negotiation managed through positions often creates a static, inflexible, and formal process, avoiding mutual cooperation and a free flow of information. The attempt to grasp to the self represents a partial perspective and limited understanding of the complex conflicting situation, as does the party's attachment to the positions and claims formed prior to the negotiation. Letting go of firm, fixed positions and a well-entrenched standpoint requires strength and awareness that, in the midst of negotiation, is hard to attain, especially in situations where a dispute is involved. Pressure, desire for control, loss aversion, and lack of faith in the possibility of an integrative outcome may all cause negotiators to avoid the relational common space, and to entrench within the firm and fixed independent positions that represent a firm and fixed independent "self,"

Bargaining Impasse: The Role of Self-Serving Biases, 11 J. ECON. PERSP. 109, 111 (1997); see also BAZERMAN \& NEALE, supra note 84; Charles G. Lord, Lee Ross \& Mark R. Lepper. Biased Assimilation and Attitude Polarization: The Effects of Prior Theories on Subsequently Considered Evidence, 37 J. OF PERSONALITY AND SOC. PSYCHOL. 2098, 2102 (1979); Michael Ross \& Fiore Sicoly, Egocentric Biases in Availability and Attribution, 37 J. PERSONALITY \& SoC. PSYCHOL. 322 (1979); Neil D. Weinstein, Unrealistic Optimism about Future Life Events, 39 J. Personality \& Soc. Psychol. 806,814 (1980).

${ }^{89}$ For more on the barrier the literature refers to as "loss aversion," see Daniel Kahneman \& Amos Tversky, Prospect Theory: An Analysis of Decision Under Risk, 47 ECONOMETRICA 263 (Mar. 1979).

${ }^{90}$ Kahneman \& Tversky, supra note 81, at 1128-29. 
resulting in a distributive rather than integrative approach and ignoring the relationality described thus far.

Fisher and Ury open Getting to Yes by defining the problem they face:

Whether a negotiation concerns a contract, a family quarrel, or a peace settlement among nations, people routinely engage in positional bargaining. Each side takes a position, argues for it, and makes concessions to reach a compromise ... When negotiators bargain over positions, they tend to lock themselves into those positions. The more you clarify your position and defend it against attack, the more committed you become to it. The more you try to convince the other side of the impossibility of changing your opening position, the more difficult it becomes to do so. Your ego becomes identified with your position. You now have a new interest in "saving face" -in reconciling future action with past positions. . . ${ }^{91}$

Fisher and Ury suggest that unlocking one's self demands a shift from positional bargaining to clarification of and deliberation over each party's interests. In the spirit of Buddhist premises, cooperation has a different meaning: the shift away from positions involves the realization of emptiness and dependent co-arising. That transformation includes realization of the illusion created when the negotiators lock themselves into positions, which represent the self, the ego. In their seminal book on negotiation, Lewicki, Saunders, and Minton write:

To sustain a free flow of information and an effort to truly understand the other's needs and objectives, negotiators may require a different outlook or frame of reference. Individual goals may need to be redefined as best achievable through collaborative efforts directed toward a collective goal. ${ }^{92}$

Lewicki et al. argue that there is a need to shift to a different outlook; however, their notion of redefining individual goals suggests including a shift to a collective goal in which the outcome satisfies the individuals' needs. According to the Buddhist philosophy, redefining the goals of the process in terms of changing the game would mean not a transformation towards a joint effort to reach a future outcome that satisfies the needs of separate individuals, with separately defined perspectives as implied in the Lewicki et al. view; but a transformation to the realization of the dependent co-arising in the common dependent co-arising space.

\footnotetext{
91 See FISHER \& URY, supra note 20, at 3-5.

92 RoY J. LEWICKI ET AL., ESSENTIALS OF NEGOTLATION 65 (1999).
} 


\section{A BUDDHIST-ORIENTED VIEW OF NEGOTIATION AND MEDIATION}

Noting the differences between distributive bargaining and integrative negotiation from a pragmatic point of view, Lewicki et al. write:

In summary, integrative negotiation requires a process fundamentally different from that of distributive negotiation. Negotiators must attempt to probe below the surface of their opponent's position to discover underlying needs. They must create a free and open flow of information, and they must use their desire to satisfy both sides as the perspective from which to structure their dialogue. ${ }^{93}$

From a relational standpoint, negotiators must probe not only below the surface of the other party's positions, but also below the surface of the other party's 'party-ness,' while recognizing they are also probing below the surface of their own party-ness. This recognition allows the free and open flow not only of information, but also of the energy that accompanies the realization of dependent co-arising, emptiness, and impermanence.

A process of integrative, relational negotiation is therefore fundamentally different from distributive negotiation. The relational tenets offer a new reading of integrative negotiation found in the ADR literature as they call for cultivating awareness of the process of dependent co-arising, mindfulness to the manner in which the relational dynamic plays a significant role in the formation of each party's separate party-ness. According to Lewicki et al, "successful integrative negotiation requires each negotiator, not only to define and pursue her own goals, but also to be mindful of the other's goals and to search for solutions that will meet and satisfy the goals of both sides." 94

Being mindful of the goals of the other party would not mean, within the relational framework of the Buddhist philosophy, to go beyond one's self and recognize the other's self (including goals and needs) but to recognize the dependent co-arising of both one's own self and the other's. Awareness to this process allows a shift in focus (as Ury suggests) from the person as the

93 Id. at 66.

$94 \mathrm{Id}$. For further readings on relational emphases within current integrative negotiation literature, see ROGER FISHER \& SCOTT BROWN, GETTING TOGETHER: BUILDING A RELATIONSHIP THAT GETS TO YES (1988); ROGER FISHER \& DANIEL L. SHAPIRO, BEYOND REASON: USING EMOTIONS AS YOU NEGOTIATE (2005); DEBORAH M. Kolb \& JUdith Williams, Everyday Negotiation: Navigating the Hidden AGENDAS IN BARGAINING (2003); Linda L. Putnam, Challenging the Assumptions of Traditional Approaches to Negotiation, 10 NEGOT. J. 337 (1994); Daniel L. Shapiro, Identity Is More than Meets the 'I': The Power of Identity in Shaping Negotiation Behavior, 87 MARQ. L. REV. 809 (2004). 
problematic entity to the discussion to the situation, the problem, 95 awareness that demands different attention in the process of relating. Umbreit, writing on negotiation and mediation from a relational point of view, alludes to this notion by stating that "[g]enuine dialogue in which people feel safe enough to speak and listen in a nondefensive manner requires skills and life perspective that many non-Western indigenous cultures are far more comfortable with than we in the West are."96

A dialogue with such qualities and skills is possible, I suggest, when "wisdom" (prajna), as understood according to the Buddhist worldview and the realization of impermanence, emptiness, and dependent co-arising take the place of "ignorance" (avidya)-the attachment to independent, unchanging, self-substantive entities.

Lewicki et al. describe four steps in a negotiation process: identifying and defining the problem, raising the needs and the interests above the surface, creating alternative solutions, and evaluating and choosing among these solutions. ${ }^{97}$ However, they add,

successful integrative negotiation can occur if the parties are predisposed to finding that mutually acceptable joint solution. Many other factors contribute to a predisposition toward problem solving and a willingness to work with the other toward finding the best solution. These factors are also the preconditions necessary for the integrative negotiation process. ${ }^{98}$

Thus, in order to go through all four stages in the integrative negotiation process, the parties must create the terms for doing so through an integrative mindset. I suggest the cultivation of mindfulness to the process of dependent co-arising and the realization of impermanence and emptiness. Therefore, in addition to the procedural stages that Lewicki et al. identify, it is important to go through preliminary stages to create the relational mindset which would allow integrative management of these stages. Umbreit writes:

This requires moving far beyond the well-known techniques of active listening or reflective listening with their emphasis on paraphrasing, summarizing and their related skills. Clearly, these techniques when used by disputants or mediators can often be very helpful in the resolution of

95 URY, supra note 21 , at 92.

${ }^{96}$ Mark Umbreit, Humanistic Mediation: A Transformative Journey of Peacemaking, 14 MEDIATION Q. 201, 202 (1997).

97 LEWICKI ET AL., supra note 92, at 111.

98 Id. at 128. 


\section{A BUDDHIST-ORIENTED VIEW OF NEGOTIATION AND MEDIATION}

conflict. The "techniques" of listening skills can also get in the way of genuine dialogue, particularly when use leads to the inability to honor and feel comfortable with silence, to deeply reflect upon what is being said, and to reflect upon what you (the mediator) are feeling and experiencing in the present moment. 99

Moving beyond the well-known techniques of active listing may be possible by cultivating relational awareness through practices developed throughout the centuries within the Buddhist tradition to help cultivate wisdom: for example, the awareness of impermanence, emptiness, and dependent co-arising. Doing so would significantly transform the distributive mindset and I/you polarization that the parties may have brought to the table. A central quality of mind that the Buddhist practitioner cultivates, for example, is a non-judgmental state of mind. Lewicki et al. write:

when parties are engaged in conflict, they tend to become evaluative and judgmental. They view their own actions, strategies, and preferences in a positive light and the other party's actions, strategies, and preferences in a negative light. Such evaluative judgments can get in the way of clear and dispassionate thinking. Saying "Your point of view is wrong and mine is right" inhabits the integrative negotiation process because you cannot attack the problem without attacking the person who owns the problem. In contrast, depersonalizing the problem-allows both sides to approach the issue as a problem "out there" rather than as a problem that belongs to one side only. 100

${ }^{99}$ Umbreit, supra note 96 , at $201-02$. The things are written as part of an endeavor to set foundations and emphases for a humanistic model of mediation which is close in spirit to the relational worldview and transformation story set by Bush and Folger. Umbreit writes:

In order to consistently embrace a more humanistic model of mediation, a number of significant changes in the dominant Western European model of mediation are required. Although clearly not capturing the full spiritual richness of many traditional practices of indigenous people, these changes in the dominant Western European model of mediation will lead to a more transformative and healing experience of mediation.

Id. at 202. As mentioned, Umbreit elaborates in that paper on some principles that may assist in generating a meaningful humanistic dialogue. These emphases are in the spirit of the Buddhist worldview and mindfulness. They are also relevant to "parties" in a negotiation setting, having no third party neutral to help manage the dispute.

100 LEWICKI ET AL., supra note 92, at 111. 
When parties are attached to their positions they tend to be judgmental and self-righteous, seeing their view as 'right' or 'just,' and the other's view as 'not right' and "not just." A significant change in mindset, according to the Buddhist worldview, would include arriving at a spatial-perception which is non-judgmental, and letting go of the attachment to the permanent, independent self-substantive entity - an entity that is manifested in one's own firmly perceived self as well as the other's firmly perceived self, both holding to firmly perceived, right and just positions. ${ }^{101}$ Transforming that mindset does not mean nullifying rightness and justness or relativizing these values. It is not that the "right" is to be nullified in the sentence "I am right," or the "just" in the sentence "I am just." Transforming ignorance and cultivating a mindful mindset means nullifying the "I am" in the sentence "I am right," and nullifying the "I am" in the sentence "I am just." It does not involve giving up on one's self in the name of giving in to "the other"; 102

101 While practicing mindfulness meditation, the practitioner learns not to filter or reject but to observe all that rises and passes away. Riskin writes:

In mindfulness meditation, a person seeks to develop 'bare attention,' or presence, i.e., to notice, without judging and with equanimity, whatever passes through her awareness-bodily sensations, emotions, sounds and thoughts .... The mediator gradually expands her awareness to include bodily sensations, emotions, thoughts, and eventually, consciousness itself - or the operation of the mind.

Riskin, supra note 44, at 23-25 (2002). Riskin continues to describe a (not unusual) report of a mediator, in which she describes what arose during her meditation:

...hearing ... enjoying... buzzing in my feet... fear: will my feet be o.k.?... hearing ... breathing ... wondering: will my parents read this article? ... enjoying ... afraid ... what do you think of me? ... fear ... it's o.k. . . compassion . . butterflies in belly . . f fear . . kindness . . . compassion . . . hearing ... bird, house finch ... naming ... thinking ... joy. ...

Id. at 25 (quoting Jennifer Egan, Walking Toward Mindfulness: Where Meditation Is Going, N.Y. TMES MAG., MAY 7, 2000 at 86). Cultivating a flowing, un-attaching mindset that notices ideas without filtering brings along a non-judgmental mindset, realizing the emptiness of the "thing" judged.

102 For further elaboration, see the distinctions between different styles of negotiation as analyzed in KENNETH W. THOMAS \& RALPH KILMAN, CONFLICT MODE INSTRUMENT (2002), available at http://www.kilmann.com/conflict.html. There, the authors distinguish between five styles, while presenting "surrendering" as one of five styles, in which one gives up on one's own will and needs for the benefit of the other party. "Cooperation" is one other style. My claim is that letting go of the self and of the positions is a necessary condition to create cooperation in its deepest sense, a cooperation based on recognition in the emptiness of that "self," its impermanence, and dependent coarising. This kind of letting go is not surrender or giving up on one's self on behalf of the 


\section{A BUDDHIST-ORIENTED VIEW OF NEGOTIATION AND MEDIATION}

rather, it involves recognition of the dependent co-arising process of all that occurs in the common space, including the "right" and the "wrong," the "mine" and the "your," if a relationally based integrative negotiation is sought.

Accordingly, the basic principle that Fisher and Ury present, "separate the people from the problem," 103 gets, accordingly, a supplemental meaning within the relational framework as presented thus far: focusing on the problem. ${ }^{104}$ This principle aims to transform the focus on "persons"-who are usually perceived as permanent, essential and independent from "the other side"- to a focus on an impermanent, ever-changing problem. This problem is compounded from needs and interests that are not static and independent like positions, but reciprocal, in an interactive, dependently coarising situation. . $^{105}$

The distinction made by David Lax and James Sebenius between "claiming value" and "creating value" 106 clarifies this point: while claiming value emphasizes the distinctiveness between parties with separate, firm and unchangeable needs, creating value requires more than perceiving the parties as separate selves. In value claiming," $[t]$ he object of negotiation is to convince the other guy that he wants what you have to offer much more than you want what he has."107

other. I will elaborate on that quality while clarifying the notion of compassion in Buddhism in a later chapter.

103 See URY, supra note 21.

$104 \mathrm{Or}$, as Ury further develops this point in Getting Past No, the turn from "the people" to "the situation."

105 Winslade and Monk speak in the Narrative framework of "externalizing," asserting that

externalizing descriptions help to extract people from a close attachment to the conflict as an expression of who they are. So what do we mean by externalizing? The spirit of it lies in the aphorism mentioned in chapter five, 'the person is not the problem; the problem is the problem.

WINSLADE \& MONK, supra note 4, at 142 . The aphorism mentioned twice by Winslade and Monk resembles Dogen's Zen aphorism "Flowers don't blossom in the spring; the blossoming of flowers is the spring." Winslade and Monk emphasize that "this is not just a gimmicky statement. It implies a belief about the nature of human problems that is different from the one that dominates most psychological, legal, and lay discourses" Id. at 143 .

106 David A. Lax \& James K. Sebenius, The Manager as Negotiator: BARGAINING FOR COOPERATION AND COMPETITIVE GAIN 30-32 (1986).

$107 \mathrm{Id}$. at 32 . 
Thus, the emphasis is on parties' separateness and distinctness. ${ }^{108}$ In "creating value," on the other hand, emphases are different:

Value creators advocate exploring and cultivating shared interests in substance, in maintaining a working relationship, in having a pleasant nonstrident negotiation process, in mutually held norms or principles... We create value by finding joint gains for all negotiating parties... The parties can treat the negotiation as solving a joint problem; they can organize brainstorming sessions to invent creative solutions to their problems. They may succeed by putting familiar pieces of the problem together in ways that people had not previously seen, as well as by wholesale reformulations of the problem. ${ }^{109}$

Lax and Sebenius also work within the pragmatic framework where 'joint gains' are perceived as means of satisfaction of parties' needs and interests. From a relational perspective, "putting familiar pieces of the problem together" may include questioning the formulated perception of the self which characterizes value claiming and, through the lens of Buddhist philosophy, exploring and cultivating new ways to understand the common dialogic space in which parties are interdependent. Buddhist philosophy suggests that this reformulation relates to the familiar pieces of "I" and "you," or to any components of the situation commonly perceived in a nonrelational manner. They are realized to be empty in themselves, where the "I" cannot be seen as such without the "you" that is dependently co-arising with "the other." 10

108 Id. at 33. "The hardest of bargainers will threaten to walk away or to retaliate harshly if their one-sided demands are not met." Id.

${ }^{109}$ Id. at 31-32.

110 The realization of dependent co-arising, emptiness, and impermanence would include avoiding an either/or polarizing logic and mindset in which two separate entities firmly hold to their separate positions. The Aristotelian law of identity-according to which A will always be identical to itself (to A) due to its unchangeable independent essence-is replaced by a logic that the Buddhist philosophy offers-in which A is at the same time non-A, due to emptiness. The Aristotelian logic develops the law of identity into the law of non-contradiction (A is not non-A), while the Buddhist logic develops it into the assertion that ' $A$ is non- $A$,' "[a]s long as one remains at the level of ' $A$ is $A$ ', i.e. the level of empirical experience," explains Izutsu,

one would never be able to say at the same time ' $A$ is non- $A$ ', unless one goes out of one's mind... Otherwise expressed, the making of an assertion of this sort presupposes on the part of the person the actualization of a total transformation of consciousness in such a way that he is thereby enabled to witness A as it 'becomes' 


\section{A BUDDHIST-ORIENTED VIEW OF NEGOTIATION AND MEDIATION}

Lax and Sebenius bring the notion of interdependence forth in the opening pages of their book, stressing its centrality to integrative negotiation and value creation, "mutual dependence implies limits to how much one party can do alone, or at what cost, or how desirably joint action may be preferable for everyone. This possibility makes interdependence a key element that defines negotiating situations."111

The Buddhist worldview gives the notion of interdependence new meaning, emphasizing the limits of perceiving the party alone from the joined action. The shift from positions to interests can be viewed, accordingly, as a shift from a one-dimensional perspective which sees fixed, entrenched, and independent entities to a mindset which values impermanence, emptiness, and dependent co-arising, as characteristics of their claims. This does not imply that the parties are empty of self-interests, i.e., concluding that "everything changes and passes and therefore is not that important; it is the relationship that is important;" rather, it creates a dynamic mindset aware of the changing context, realizing the interests as they arise in it. In other words: attachment to the positions means avoiding the relational dynamics of interdependence and formulating the illusionary selfsubstantive, permanent, and independent "self" whose relations to the other are viewed in a fixated (mostly negative) manner. It corresponds with the

A itself to such an extent that it breaks through its own A-ness, and begins to disclose to him its formless, essenceless, and 'aspect'-less aspect.

IZUTSU, supra note 49, at 29. Therefore, things cannot be perceived as "either A or non$\mathrm{A}$ ", in an either/or polarizing state of mind. In addition, while the Aristotelian law of identity defines the boundaries between $A$ and $B$ in a definite way (as A-ness and B-ness hold differing characteristics by definition), the Buddhist presuppositions do not lead to such conclusions. The clear distinction between "party A" and "party B," each holding "positions A" and "positions B," is questioned.

111 Id. at 7; see also MNOOKIN ET AL., supra note 79, at 40 (emphasizing that in order to generate value-creating options, it is important to treat distributive issues as a joint problem). Mnookin et al. write:

What happens to interest-based, collaborative problem-solving when you turn to distributive issues? Some negotiators act as if problem-solving has to be tossed overboard when the going gets tough. We could not disagree more. In our experience, it's when distributive issues are at the forefront that problemsolving skills are most desperately needed. [The] goal at this point is to treat distributive issues as a shared problem.

Id. 
inability to manage the conflict within the common dialogic space. ${ }^{112}$ The goal at this point would be, therefore, to return to the mindset of continuous change and interdependence. ${ }^{113}$

The emphasis is twofold-both on change and on the interaction that creates that change. 114 In "Difficult Conversations," Douglas Stone, Bruce Patton and Sheila Heen write:

112 Riskin's description of mindfulness meditation and the manner in which cultivating mindfulness assists in the realization of dependent co-arising and the continuous changes can be seen in the following:

[M]indfulness meditation can help people develop an ability to pay attention, calmly, in each moment, which they can apply in everyday life. It enables us to see how our minds work, to experience our lives more fully. Observing the mind's operation in this way helps us notice the kind of randomness and impermanence revealed in the mediator's narration above... Through mindfulness practice, we can recognize this [a certain reaction to outer occurrence] as simply one of our habitual reactions to certain kinds of situations. Such recognition can give us the power to watch such phenomena rise and fall away, rather than getting caught up in them.

Riskin, supra note 101 , at 26 . Just as a practitioner of mindfulness meditation develops awareness to the inner voices of the mind by cultivating the realization of impermanence, emptiness, and dependent co-arising, a negotiator who wishes to transform the positional mindset should develop similar awareness, in order to truly delve beneath positions.

113 When characterizing "interests," to which one shifts from the fixed and firm independent positions, Lewicki et al. emphasize a pragmatic view of both their interdependence and impermanence. Interests are complex, are varied, and interdependent, both on the intra-personal and the inter-personal level. It seems that Lewicki et al. alludes to the notion of interdependence when stressing that "there is always more than one type of interest in a dispute ... parties can have different types of interests at stake." LEWICKI ET AL., supra note 92, at 116. The difference in interests allows the realization of interdependence. Multitude and differentiation enables a shift from what is perceived in the Buddhist worldview as the illusion of independence, to exploring the interdependent nature of the. Interests are also impermanent, as "interests can change ... interests can change over time. What was important to the parties last week, or even twenty minutes ago, may not be important now. Interaction between the parties can put some interests to rest, but it may raise others. Thus, the parties must continually be attentive to changes in their own interests and the interests of the other side. As we will point out, when one party begins to talk about things in a different way, when the language or emphasis changes, the other party may look for a change in interests." Id. at 117.

${ }^{114}$ Id.; see also Clark Freshman, Identity, Beliefs, Emotion, and Negotiation Success, in THE HANDBOOK OF DISPUTE RESOLUTION, supra note 87, at 99 (arguing that identity, beliefs, or emotions can be dysfunctional and disruptive to the negotiation process when instead of having flexibility with regard to them, negotiators have a fixed perception of them). Freshman writes:"Our fixed identity-I must do this because this is 


\section{A BUDDHIST-ORIENTED VIEW OF NEGOTIATION AND MEDIATION}

One way to shift your stance from the easy certainty of feeling that you've thought about this from every possible angle is to get curious about what you don't know about yourself. This may sound like an odd thing to worry about. After all, you're with yourself all the time; wouldn't you be pretty familiar with your own perspective? In a word, no. The process by which we construct our stories about the world often happens so fast, and so automatically, that we are not even aware of all that influences our views. $^{115}$

What Stone, Patton, and Heen tell us is that one should open up to the situation in which one takes part and to the ability of changing one's own firm positions or ideas about the dispute that were shaped prior to the mediation or negotiation. It is certainty that one supposedly has, for it is without engagement and inquiry within the common space that this certainty develops. With the Buddhist understanding of change and of the need to transform attachment to firm unchanging and separate ideas, Lewicki, Sunders, and Minton's suggestions on decisionmaking in an integrative negotiation process may be understood in a new manner: "Keep decisions tentative and conditional until all aspects of the final proposal are complete. Even though a rather clear consensus may emerge about the solution

who I am-can look a lot like just another example of positional bargaining." Id. "People may feel," he continues, "that they have to be consistent with some identity, and this is one way to understand why individuals may bargain when they do." Id.

One unfortunate aspect of traditional conversation is that we are positioned as unified egos. That is, we are constructed as singular, coherent selves, not fragmented and multiple ones. To be incoherent is subject to ridicule; moral inconsistency is grounds for scorn. Thus, as we encounter people whose positions differ from ours, we tend to represent ourselves one dimensionally, ensuring that all our statements form a unified, seamless web. As a result, when we enter a relationship defined by our differences, commitment to unity will maintain our distance. And if the integrity or validity of one's coherent front is threatened by the other, we may move toward polarizing combat.

Kenneth. J. Gergen, Mary M. Gergen \& Frank J. Barrett, Dialogue: Life and Death of the Organization, in THE SAGE HANDBOOK OF ORGANIZATIONAL DISCOURSE 40 (David Grant et al., eds. 2004).

115 Douglas Stone, Bruce Patton, \& Sheila Heen, Difficult Conversations: How to Discuss What MATTERS MOST 38 (1999). When discussing the "Identity Conversation," Stone, Patton, and Heen suggest that one should complexify one's identity, arguing that telling reporting to one's self that "I'm always a good listener" is an oversimplification of the world, as "no one is always anything. We each exhibit a constellation of qualities, positive and negative, and constantly grapple with how to respond to the complicated situations life presents." Id. at 118 . 
option(s) that will be selected, the parties should talk about the solution in conditional terms. ${ }^{116}$

A "tentative tone" which allows change, revision, non-attachment, and fixating to earlier decisions, may be attained by cultivating the mindset and realizing the premises discussed thus far. ${ }^{117}$ Regarding the motivation and commitment to work together, Lewicki et al. write, "[f]or integrative negotiation to succeed, the parties must be motivated to collaborate rather than to compete. They need to be committed to a goal that benefits both of them rather than to pursuing only their own ends." 118

In order to adopt interpersonal styles that are more relational, I suggest, a thorough transformation of combative and evasive style that addresses defensiveness and stubbornness through the realization of impermanence, emptiness, and dependent co-arising. This transformation may allow alleviation of the fixed positions and rigid mindset in a manner that brings to a "process fundamentally different" (as Lewicki et al. call for), or to "changing the game" (as Ury suggests). ${ }^{119}$ The transformation will be based on a fundamentally different philosophy and way of looking at conflict situations, inspired by Buddhist philosophy and view of transformation-a way which is different in its underpinnings from those embedded in the frameworks presented by Fisher and Ury, Lewicki et al., Lax and Sebenius, and others. It is my belief that this way of looking at conflict and its transformation sheds light on the analysis suggested by these writers, and offers new modalities for an integrative style of negotiation.

116 LEWICKI ET AL., supra note 92, at 83.

117 Moreover, Lewicki et al. emphasize suspension of judgment while generating value-creating options: "Avoid judging or evaluating solutions: ... Criticism inhibits creative thinking. Creative solutions often come from ideas that initially seemed wild and impractical. No idea should be evaluated or ruled out..." Id. at 121. A Buddhist worldview would facilitate this suspension of judgment, being, as mentioned, one of the qualities of mind the practitioner cultivates. Lewicki et al. write, "brainstorming processes are often constrained because the parties take ownership of certain preferred solutions and alternatives" Id. at 122. Taking ownership has two aspects: losing the realization of the co-arising common space, and returning to the party-ness. This shift in focus substitutes an awareness of constant change with an illusion of permanence. Fixating on and entrenching in "a solution," as well as on a firm view of "the problem," is an attachment (upadana) which Buddhism characterizes as a fundamental source of the suffering and dis-ease that needs to be transformed.

$118 \mathrm{Id}$. at 85.

119 URY, supra note 21 , at 84. 


\section{A BUDDHIST-ORIENTED VIEW OF NEGOTIATION AND MEDIATION}

\section{CONCLUSION}

Buddhist philosophy offers an important challenge to the field of conflict resolution on both the theoretical and practical levels. On the theoretical level, it encourages a reexamination of deep-rooted philosophical assumptions and mental constructs, some of which are non-critically held as given. Buddhist philosophy will allow an expansion of the discourse over the theoretical foundations of collaborative practices offered by the ADR field, and will generate new insights due to cross-fertilization between different worldviews. On a more practical level, Buddhist philosophy may offer new emphases, skills, and techniques to support the transformation from an adversarial to a relationally-based integrative mindset, thus helping parties overcome their deeply rooted beliefs and non-integrative dis-ease when in conflict.

According to Lewicki et al., "listening to your own inner voices-fears, aspirations, hopes, desires-is important in bringing your own interests to the surface." 120 The inner voice lies at a deeper layer than positions. This voice, according to the Buddhist worldview, also helps reveal a layer deeper than that of one's own interests. Transforming to a relational integrative style of negotiation requires a transformation of one's mindset, achieved through practice and relational experience. Revealing needs and interests is only one stage; realizing impermanence, emptiness of separate self, and the Buddhist understanding of dependent co-arising is another stage. Such realization, as described, allows the establishment of a relational common-space in practice. It is a deeper transformation, in which cooperation in its deepest sense is taking place.

Transforming any conduct, by transforming its root causes, demands going to the roots on both the philosophical and the practical levels. This is what Buddhist thought and practice aim at in its view of transformation. It may help to radically "change the game" (as Ury describes) or "reformulate" the confrontational situation (as Lax and Sebenius suggest). The suffering/dis-ease that Riskin identifies as a derivation of an adversarial "philosophical map," as well as the philosophical premises that govern the non-relational mode of conduct in destructive conflict interaction according to Bush and Folger, and the analysis provided within the narrative mediation framework all suggest something that is consistent with the Buddhist premise - that the dominant individualistic mindset leads to the adversarial mode of conduct. In the spirit of Ury's assertion that negotiation itself is the

120 LEWICKI ET AL., supra note 92, at 117. 
road from confrontation to cooperation, ${ }^{121}$ a process of mediation or negotiation may be seen as a platform for practicing and realizing dependent co-arising, thus serving as a road from substantive metaphysics, which lies at the basis of individualistic philosophy, to a relational realization of human nature in practice.

The Buddhist underpinnings, I suggest, can therefore serve as basis to examine, challenge, and contribute to current tendencies in mediation and "integrative negotiation" literature and practice. None of this is to suggest that parties to a conflict should convert to Buddhism as a religion, or that Buddhism offers a formula with instructions for everyday proceeding that one should follow. None of this is also to suggest that the Buddhist teaching strives for harmony as commonly understood in Western culture to be a view in which differences do not exist or where conflict has been overcome. ${ }^{122}$ Rather, the project of cultivating an integrative, collaborative worldview in which conflicts are not avoided but met and constructively managed may benefit, both in theory and in practice, from the encounter with the Buddhist relational worldview and its possible manifestations in practice.

$121 \mathrm{URY}$, supra note 21 , at $\mathrm{x}$.

122 In his book, Bernie Glassman asserts that, "the first [Buddhist] peacemakers" vows taken by all members of our Peacemaker Order are: I vow to be oneness; I vow to be diversity; I vow to be harmony." BeRNIE Glassman, BEARING WITNESS: A ZEN MASTER's LESSONS IN MAKING PEACE 47 (1998). Oneness presents the overcoming of dualistic mindset "when peacemakers vow to be oneness, there is no Other." Id. at 49. Diversity is the focus on

the world of form in all its infinite variety of textures, colors, contrasts, and differences. Not only are we different from each other, but everything is different from one moment to the next-everything is change. We are all part of one single unity, but we're also very different. We can't do peacemaking in the world-in fact we can't do anything effective in the world-without taking our differences into account.

Id. at 53. The world of forms is taken into account, but forms are realized to have the characteristic of impermanence, emptiness, and dependent co-arising. Diversity, claims Glassman, is the other side of oneness, and there is no need to choose between them, either oneness or diversity, but rather see how the two arise in the common dialogic space. The realization of the formless form of the diverse forms and of the formless form of oneness and diversity themselves comprises the Buddhist notion of harmony, as presented by Glassman, to be the third vow of the Buddhist peacemaker. 